AROUEOLOGÍA Y SOCIEDAD

№ 29, 2015: 233-276

ISSN: 0254-8062

RECIBIDO: ABRIL DEL 2015

ACEPTADO: MAYO DEL 2015

\title{
LA DISTRIBUCIÓNY ORGANIZACIÓN DEL TERRITORIO DE LOS HUAROCHIRI PREHISPÁNICOS DURANTE LOS TIEMPOS TARDÍOS. ENSAYO: UNA MIRADA DESDE EL CULTO A LOS CAMAC Y LOS "HÉROES MÍTICOS- PAQARINAS O FUNDADORES".
}

\author{
BRAVO MEZA BRADYMIR BITZEN \\ UNIVERSIDAD NACIONAL MAYOR DE SAN MARCOS
}

\begin{abstract}
RESUMEN:
En el Huarochirí prehispánico de los periodos tardíos (Intermedio Tardío y Horizonte Tardío) el sentido de adscripción a una identidad étnica de los pueblos andinos se basa en el culto a los camac héroe míticos-paqarina o fundador (personaje mítico cuyas hazañas, conquistas y proyectos hidráulicos y/o agrícolas trasforman el antiguo momento y orden en que se encontraban inmersos su comunidad en uno nuevo donde la comunidad adquiere un mayor poder en el territorio andino, por lo cual las generaciones de integrantes de la comunidad se considera descendiente de este héroe mítico); la presencia del culto al Apu Huallallo Carhuincho y posteriormente al Apu Pariaqaqa, viene a ser en este contexto el engranaje conciliador y justificador de las milenarias interrelaciones y conflictos de las comunidades ancestrales, que se imponen en el territorio mediante los esfuerzos de los pueblos prehispánicos que expanden su influencia y/o control del territorio. Desde este enfoque durante el Intermedio Tardío las provincias de Huarochirí y Yauyos no habrían pertenecido a una misma identidad étnica llamada Yauyu, sino más bien se encontraría dividida en un conjunto de grupos comunales adscritos a una identidad propia en base al culto de su camac héroe mítico -paqarina o fundador fortalecida por los conflictos del pueblos andinos, pero que a su vez se encuentran estableciendo vínculos ancestrales - pero plausibles de transgredir - de culto a Pariaqaqa (el nuevo momento y orden en que se encuentra inmerso el territorio central de la sierra de lima). Durante este periodo el papel de las huacas o camac hembras es trascendental, ya que por medio de ellas los Apu y huaca pueden heredar
\end{abstract}


el antiguo momento y orden en que se encuentran las comunidades sometidas, mediante estratégicas alianzas matrimoniales. Durante el Horizonte Tardío, el auspicio del aparato estatal incaico hegemoniza el culto panregional a Pariaqaqa, y coloca a los Yauyu como administradores de su culto. No obstante que los pueblos prehispánicos de Huarochirí, comparten el mismo culto panregional con los de la provincia de Yauyos, mantienen su adscripción a una identidad común basada en el culto a sus camac héroe mítico- paqarina o fundador. Durante el Tawantinsuyu la complejidad de la organización del culto en Huarochirí bajo el dominio incaico revela un modelo de distribución territorial del tipo archipiélagos de culto (cultos a camac o huacas extranjeras insertadas en cultos locales) como estrategia de control.

Palabras Claves: Camac héroe mítico -paqarina, fundador, archipiélago de culto, Yauyu, adscripción étnica, Huarochirí, heredad del momento y orden.

\section{Abstract}

In pre-Hispanic Huarochirí of later periods (Late Intermediate and Late Horizon) the sense of membership of an ethnic identity of the Andean peoples is based on the cult of the hero camac mythical-paqarina or founder (mythical character whose exploits, achievements and projects hydraulic and / or agricultural transform the old times and order in which they were immersed in a new community where the community acquires a greater power in the Andean territory, so generations of community members is considered a descendant of the mythical hero ) the presence of cult Huallallo Carhuincho Apu Apu Pariaqaqa and then, becomes in this context the conciliator gear and justifier of the ancient relationships and conflicts of ancestral communities, which are imposed on the territory by the efforts of prehistoric peoples they expand their influence and / or control of territory. Since this approach during the Late Intermediate provinces of Huarochiri and Yauyos not have belonged to the same ethnic identity called Yauyu, but rather find divided into a set of community groups attached to an identity based on the cult of the mythical hero camac founder -paqarina or strengthened by the conflicts of the Andean peoples, but which in turn are establishing ancestral links - but plausible to transgress - Pariaqaqa cult (the new time and order in which is immersed in the central area of the Sierra de lime). During this period the role of females is camac huacas or transcendental, because through them the Apu huaca and can inherit the ancient times and order in which they are subjected communities through strategic marriage alliances. During the Late Horizon, sponsored by the Inca state apparatus hegemonizes Pariaqaqa pan-regional cult, and puts Yauyu as stewards of their worship. Although the prehistoric peoples of Huarochiri, share the same pan-regional cult with the province of Yauyos, they maintain their allegiance to a common identity based on hero worship their camac paqarina or mythical founder. During the Tawantinsuyu complexity of the organization of worship under the Inca rule Huarochirí reveals a pattern of territorial distribution of the archipelagos of worship (cults camac or foreign huacas inserted in local cults) as control strategy type.

KeYwords: Camac -paqarina or mythical hero, founder, archipelago of worship, Yauyu, ethnic affiliation, Huarochirí, inherit the moment and order. 
“...cultura no es igual a etnia. El arqueólogo puede conocer la cultura, pero no puede definir etnia"

(Bazán 1990: 216)

\section{PreÁmbulo}

Es innegable que la explicación etnohistoricista ha sentado un precedente contextual de fuerte impacto para las investigaciones arqueológicas de la costa central, a tal punto que en nuestra visión condensada de las investigaciones bajo este supuesto, se ha visto en la necesidad de definir la problemática prehispánica de la organización y distribución del territorio, bajo el fundamento étnico, contextualizando el espacio de los valles de Chancay, Chillón, Rímac, Lurín, Mala y Omas en grandes grupos prehispánicos para los periodos tardíos: los Collí para el bajo Chillón, los Canta y Atavillos para el alto Chancay y Chillón, los Ychsma para los bajos Rímac y Lurín, los Yauyus para los altos Rímac, Lurín y Mala, y Guarco en el bajo Mala y Omas. Esta visión del panorama prehispánico de los periodos tardíos prehispánicos (Intermedio Tardío y Horizonte Tardío), sobre todo para la sierra central, resulta demasiado generalizada. La discusión que a continuación presentamos, discusión de esta forma de ver la distribución y organización del territorio en la costa central, tiene un frente específico de desarrollo, debido a que ya solo el espacio geográfico mencionado es de por sí muy complejo como para abordarlo por entero. Este estudio se centra pues en discutir y proponer desde la etnohistoria una alternativa a esta explicación etnohistórica, tomando como punto de estudio el caso de los pueblos de Huarochirí y Yauyos, y usando el criterio discriminador del culto a las llamadas "deidades" para definir la etnicidad y el territorio.

\section{CONSIDERACIONES}

Según Barth la categoría de etnia señala dos características principales: 1) una cultura común, 2) y la adscripción a una identidad común (Barth 1969). Bazán ha discutido la problemática que suponen estas dos características (Bazán 1990: 213-215):

La primera de las características supone responder a dos problemas:

1. La continuidad de la naturaleza de las etnias.

2. La variedad adaptativa de una etnia a una ecología.

La segunda, supone adscribirse a rasgos "significativos", y "no objetivos". Se estaría caracterizando por:

1. Presentar signos manifiestos de exhibición: como la vestimenta, el lenguaje, vivienda y modo de vida.

2. Presentar valores básicos: normas morales y de excelencia.

Es difícil sostener la definición de grupos étnicos a raíz de la cultura material común. La continuidad de los rezagos de la cultura material de grupos más antiguos en grupos comunitarios más recientes puede verse desde la perspectiva del arqueólogo como indicadores de diferencia étnica. Un grupo étnico definido, puede, como sucede muy a menudo en los Andes, establecerse en un espacio de ecosistemas, ecología, geografía, multivariada. La adaptación a esta variabilidad geográfica de los grupos comunales pertenecientes a un mismo grupo étnico, casi siempre se traduce en la readaptación de la cultura material a las nuevas condiciones geográficas y laborales. Por ejemplo, no serán iguales los materiales culturales, ni el patrón arquitectónico con que se construyen los asentamientos de los 
Chupaycho de Huánuco en las tierras cálidas de cocales, con el de los Chupaycho establecidas en las punas para el pastoreo del ganado. Esta heterogeneidad en la cultura material también se traduce en términos de variabilidad cerámica. El contacto de dos grupos comunitarios periféricos adscritos a diferentes organismos étnicos centrales puede prestarse rasgos estilísticos sin la necesidad de cambiar de adscripción étnica, lo que generalmente sucede en los espacios de contacto periférico de grandes grupos organizados. De ahí como dice Bazán que para definir un grupo étnico lo primero a definir es la adscripción a una identidad específica, la cultura común es secundaria (Bazán 1990: 215) y como se ha visto no es un marcador determinante ni exclusivo de identidad étnica ${ }^{1}$.

Si bien es cierto, como lo señala Bazán, la adscripción a una identidad común, se puede expresar en signos manifiestos de exhibición, y los valores básicos comunitarios, el nivel de esta adscripción debe fijarse a nivel de trascendencia comunal o de los ayllus, y esta fijación ha de ser profunda a nivel de las estructuras mentales comunales, para que el sentido de pertenencia a un orden determinado se traduzca en la posibilidad de evidenciar una identidad comunitaria. Pensamos que en el mundo Andino este tipo de adscripción tiene su mejor reflejo en el culto a las huacas y/o camac" "animadores de los hombres". Ahora bien, debemos reconocer un problema evidente, y es que este sentido de adscripción a una identidad de culto se manifiesta en términos estructurales: el runa se adscribe desde el culto a los camac familiares, el culto a los camac comunales, el culto a los camac regionales, hasta el culto a los camac del pacha o pan-andinos o llamados tunapa (u ordenadores del mundo), desde el culto a los camac de la naturaleza, de la fertilidad y sexualidad, al mismo tiempo dentro de sus relaciones comunales, es decir se adscribe al culto de varios camac durante su existencia como individuo perteneciente a un ayllu y en la comunidad de los ayllu. Y es que en el mundo andino hay una gran complejidad y variabilidad de camac con los cuales el runa y el ayllu pueda identificarse (por ejemplo puede identificarse con la Pachamama con la cual todos los runas del mundo andino se identifican -y esto no significa que debamos definir a todos los runas de los Andes como la etnia de Pachamama-, con Tutayquire como camac de su comunidad, y con Pachacamac por los favores recibidos, con lo cual todos los necesitados pueden identificarse, sin la necesidad de sentirse representados por este camac, al menos en tiempos del Tawantinsuyu). No obstante la contraparte a este problema, señala que este sentido de múltiple adscripción cultista comunal, en el mundo Andino, sucede con respecto a cada camac, con diferentes grados de intensidad y sobre todo pertenencia. Tal parece y entonces sostenible, que dentro del panteón de camac y huaca comunales existen niveles jerarquizados del culto ejercido, estarían relacionados estrechamente con el grado de funcional importancia y de ancestralidad de estos. Por lo cual se piensa debe existir una categoría de camac que defina la identidad comunitaria

1. No obstante esta vía de definición étnica es más difícil si se pretende emprender el camino desde la arqueología. Aquí esbozamos un esfuerzo desde la etnohistoria. En lo sucesivo (y en otro trabajo) intentaremos justificar las propuestas de este ensayo con evidencia arqueológica, aunque sospechamos desde ya que dicha confrontación terminará por modificar mucho de lo expuesto a continuación.

2. G. Taylor considera que el lexema cama- (/kama/) no corresponde en la religión precolombina al concepto cristiano de "crear" sino que indicaba la transmisión de la fuerza vital de una fuente animante (camac), generalmente un dios regional o un antepasado, a un ser u objeto animado (camasca) (Taylor 1987). En la llamada "religión" andina, el término "dios", en el sentido que le otorga el cristianismo y que se aplica por los investigadores occidentales, no era pues aplicado por los runas del mundo andino. El gran ente, centro de sus veneraciones debe entenderse como camac, la fuerza vital que anima a los hombres (Taylor 1987, 2000). Por lo cual los llamados "dioses" andinos no son en realidad dioses creadores, sino fuerzas animadoras, energías animadoras. Pariacaca, Huallallo Carhuincho, Chaupiñamca, Pachacamac, Cuniraya, e incluso en Apu Conticsi Viracocha Pachayachachic, deberían ser entendidos como camac, y no con la definición simplona de dioses. Se aprovecha este ensayo para reivindicar dicho término, y en lo sucesivo se sustituirá el término "deidad", "dios", por el de camac. 
con un sentido más marcado de necesidad, pertenencia y ancestralidad. Al menos para el caso de Huarochirí, en la sierra de Lima, se propone que esta categoría de camac es el "héroe mítico - paqarina o fundador". Se volverá más adelante a fondo sobre este punto.

P. Gose, en su análisis de los fundamentos del poder político y administrativo imperial inka sostiene que este se encuentra ligado al control de la organización segmentaria y jerarquizada del culto a las huacas, a través de intentos estatales de controlar el flujo y ritual del agua por medio de las fronteras de la vida y la muerte (Gose 1993). En esta interpretación se pone de por medio la estrategia de dominación inka de asegurar el control de la ritualidad a las huacas como medio de controlar el poder y la organización administrativa de los grupos locales. En otras palabras el culto a una huaca puede estar definiendo un grupo comunitario determinado, organizado en prácticas rituales compartidas, y asentada sobre un espacio geográfico donde el grupo comunitario en mención ejecuta el uso y consumo de las tierras comunales y el aprovechamiento del agua.

Al respecto Sabino Arroyo nos dice que en el aspecto político-religioso, la ruta de los personajes míticos marca puntos de encuentro y límite, fronteras económicas y culturales o centros de control y contacto social. Por lo que, los ríos, quebradas y las montañas tienen su sustento sagrado o son receptáculos del contenido social y cultural, según el paso del tiempo (Arroyo 2006: 17). La posibilidad de que el culto a estos personajes míticos -generalmente conocidos como huacas y siempre entendidas como camac- permitan establecer fronteras de organización económica y cultural, sugiere sustentar la determinación del territorio andino a través del culto a las deidades. Esto se estaría dando en el mundo andino, debido al alcance trascendental y el rol medular que juegan los camac o huaca en la justificación de la existencia de los runas, el ayllu, y las comunidades prehispánicas. Como escribió Arriaga, "cada división de un ayllu tiene una huaca principal". Los ayllus que estas deidades definen no sólo eran jurisdicciones de culto, sino también unidades cuasi-administrativas. No había ninguna comunidad andina separada de la religión y la organización política (Gose 1993).

En definitiva a los "dioses andinos"3 protectores de los lugareños, siempre se los ubica en las montañas sagradas y sus espacios de dominio siempre están delimitados por los ríos y quebradas. Asimismo, sus relaciones de parentesco y de intercambio siempre son demarcados según sus rangos o jerarquías de la zona o región; lo que al mismo tiempo denota, que el dominio de los dioses andinos no sólo demarcan espacios étnico-culturales o fronteras político-territoriales, sino también, constituyen una forma de legitimar los puntos de referencia, control y dominio del espacio cultural (Arroyo 2006: 17).

Los cronistas cristianos, en sus muchos documentos que nos han legado, coinciden al menos en dos implicancias sobre las huacas, estos se entienden, comúnmente, o como "templo de los ídolos, o el propio ídolo". En el mundo Andino prehispánico estos eran considerados como antepasados que fundaron grupos de descendencia (ayllus). Son por ende los runapcamac ${ }^{4}$ o "animador de la humanidad".

3. Confiamos más en los términos andinos, como el que usa Sabino Arroyo, Apu Wamanis, en lo particular se agrega camac porque se considera el equivalente general de deidad entendido en una visión propiamente andina, es decir el sentido de animación antes de creación.

4. La literatura especializada, generalmente ha traducido este término como "creador de la humanidad". Como lo he señalado anteriormente, no hay razón para atribuir el criterio cristiano de creación a las huacas. El termino runapcamac, está constituido por el término camac, que siguiendo la propuesta de Taylor significa "animar", por lo que traducimos runapcamac como "animador de la humanidad". En la versión original de Gose se ha traducido como "creador de la humanidad", por lo que la modificación de esta parte citada es de responsabilidad de quien escribe este ensayo. 
A la huaca se les ha atribuido los dones de la fertilidad, de su generosidad depende la cosecha de la tierra y la reproducción del ganado; y sobre todo el dominio sobre el agua, muchas de las funciones, nombres, y sacralidad de las huacas se debe a su relación con las lluvias, ríos, lagunas, puquiales, necesarios para la vida. Está claro que el agua es el fundamento central que rige todo el orden del mundo del hombre andino, a tal punto que sin el agua se creyera imposible subsistir. Gose señala que el ritual del agua se debe a la creencia del hombre andino de que eran incapaces de controlar el agua, y por ende su subsistencia agraria, dentro de sus límites políticos localizados (Gose 1993).

En la medida que nos permiten los documentos etnohistóricos, sostengo que en la costa central, una perspectiva potencial y alternativa de atribuir la categoría de etnicidad a un grupo o conjunto de grupos prehispánicos es a raíz de la evaluación del culto a los camac, así cabe la posibilidad de encontrarnos con dos alternativas para entender la territorialidad a través del culto en este espacio geográfico: primero y pensado para toda el área de la costa central, donde la etnicidad puede expresarse en el sentido de adscripción a la identidad del culto compartido a un camac regional, cómo sería el caso de Pariaqaqa o Pachacamac. Segundo, para el caso de la sierra de Lima, el cual se propone discutir aquí desde una mirada al caso huarochirano, donde la etnicidad puede expresarse en el sentido de adscripción a la identidad del culto a una categoría definida de camac, el "héroe mítico-paqarina o fundador"5. En lo particular aquí nos inclinamos por la segunda opción, teniendo en cuenta que el camac "héroe mítico-paqarina o fundador" puede alcanzar la categoría de camac regional.

Los términos gramaticales que componen esta categoría de camac, no es casual, sino se encuentra inducida por lo que nos sugiere la interpretación de las fuentes etnohistóricas de los siglos XVI-XVII de la sierra de Lima.

El camac héroe mítico-paqarina o fundador se explica en el criterio de ancestralidad representada en las huacas como punto de referencia para el runa, el ayllu y la comunidad. Una buena explicación de este criterio de ancestralidad nos la refiere Gose: "Estos ancestros eran gobernantes muertos que en vida habían conquistado nuevos territorios o ampliado las fronteras agrícolas a través de terrazas y riego. Debido a sus hazañas se convertirían en piedra y permanecerían conectados a sus reinos como un antepasado-deidad que siguió proporcionando la vida, la fertilidad agraria, y asesoramiento oracular sobre los asuntos de Estado... Como ex gobernantes que representan las áreas que habían conquistado y colonizado, las huacas eran modos de organización política que podrían formar redes más grandes" (Gose 1993). En la cita anterior de Gose, podemos encontrar los fundamentos que nos permite hablar del héroe mítico, y por lo cual este llega a ser huaca y por ende camac.

Por paqarina entendemos "punto de origen o nacimiento" del cual desciende un ayllu o comunidad. Este por lo general es el lugar mítico, de la que han surgido los hombres en el mundo desde el subsuelo, este puede ser una cueva, montaña, fuente de agua, lago, o pies de los árboles, y en ocasiones de un animal. Es en otras palabras el justificador del runa para pertenecer a un lugar en específico.

5. Ya Taylor sugería que ciertos personajes míticos representaba a un héroe antiguo-fundador de linaje. Él nos dice de este que era deidificado por la tradición popular, la traducción de llactachascan por “(como) fundo su comunidad”, será coherente. Existe también la posibilidad de que se trate de la creación de una nueva humanidad (o civilización), conforme a tradiciones análogas relatadas por los cronistas de la conquista. Sin embargo, la asociación íntima en la religión andina entre el concepto de comunidad y dios tutelar (ambos expresados por el término llacta en el manuscrito) autoriza también otra interpretación de llactachascan en este contexto: es decir,... "huaca protector étnico.... "(Taylor 1987: 145) 
Por fundador nos referimos al vehículo que termina con un tiempo y orden viejo e inicia un nuevo tiempo y orden. Entendamos una particularidad de esta función que se manifiesta en Huarochirí con el siguiente ejemplo: de un grupo de varios ayllu identificados como una identidad comunitaria surge un personaje "mítico" que emprende valerosas hazañas para el beneficio de su ayllu, o para mejorar el estatus de este ayllu. Las consecuencias son la apropiación de nuevas y ricas tierras que le permiten equiparar el poder de su ayllu con el de toda la comunidad de restantes ayllu juntos, este por ende forma una nueva comunidad, en otras palabras rompe con un antiguo tiempo y orden e inicia uno nuevo. No obstante sus lazos de identidad de pertenencia lo llevan a seguir hermanado a la comunidad del cual desciende. Ahora bien, este personaje "mítico", con el tiempo y para su ayllu, se le mitificará por aperturar este tiempo y orden nuevo donde son más "poderosos" que antes. Esto puede llevar al personaje a alcanzar una categoría equivalente aunque no igual a la de paqarina, pues de el desciende una nueva generación de hombres inscritos en un tiempo diferente. Aun así el sentido de pertenencia sigue vinculado a la paqarina del antiguo tiempo y orden, lo cual en términos estrictos los obliga a renovar los lazos de hermandad con la comunidad del cual formaban parte, y con la paqarina de donde aparecieron en el mundo. Este sería el caso de Tutayquire con Pariaqaqa, el cual veremos más adelante.

Vale resumir, que al referirnos a la categoría de camac "héroe mítico- paqarina o fundador", estamos atribuyendo un: 1) vehículo de identidad ancestral (que viene a ser el héroe mítico); 2) un vehículo de pertenencia a un lugar (que viene a ser la paqarina); y 3) un vehículo de pertenencia contexto-temporal a un momento y orden (que viene a ser el fundador). Y al referirnos a este como camac, debemos entenderlo como la "energía que anima a los hombres".

Finalmente es necesario aclarar que en el mundo andino este tipo de demarcación territorial, no implica la determinación rigurosa de fronteras ni límites determinados, estas parecen ser flexibles y se inscriben en el paisaje de forma salpicada y discontinua (Murra 1975, Astuhuaman 2011). Las fronteras de culto también parecen inscribirse bajo este principio. Más adelante intentaremos discutir y justificar una explicación a dicha discusión.

\section{LOS YAUYUS ¿UN GRUPO ÉTNICO DE LAS SIERRAS DE LIMA DURANTE EL INTERMEDIO TARDIO?}

Se ha dicho, que en tiempos prehispánicos los pueblos de Huarochirí y Yauyos conformaban un poderoso grupo étnico llamado "Yauyus" (Rostoworowski 1977, 1978; Carcelén 1996; Gentille 1976, 1977; Bazán 1990). Según las interpretaciones hechas de los documentos escritos por los cristianos españoles de los siglos XVI-XVII, la etnia Yauyus se componía por una gran cantidad de belicosas comunidades o pueblos identificados bajo un mismo discurso religioso, el culto al Apu Pariaqaqa, que ante el arribo de las fuerzas qosqeñas a la costa central fueron anexadas en calidad de aliados al creciente estado qosqeño de Pachacutic reordenándolas en dos "provincias" llamadas Lurin Yauyu (Huarochirí) y Anan Yauyu (Yauyos) que no obstante habrían mantenido su otrora identidad cultista a Pariaqaqa. Siguiendo con el desarrollo histórico de este grupo étnico, se ha dicho además, que en tiempos de la colonia las comunidades o pueblos de estas dos provincias conocidas toda por los cristianos como Hatun Yauyu, fueron desarticulados por los españoles en unas cuantas "reducciones de indios", muchas de las cuales han sobrevivido hasta nuestros tiempos. A pesar de este mecanismo de exterminio colonial, las interpretaciones etnohistóricas sugieren que estos pueblos mantenían, su misma identidad de culto al gran Apu de esta región serrana, Pariaqaqa (Rostoworowski 1977, 1978; Carcelén 1996; Gentille 1976, 1977; Bazán 1990). De ahí que Feltham, al someter a juicio los términos "yunga" y "Yauyu", concluyera que a comparación de lo que se había entendido por yunga, si era posible hablar de los Yauyos como una identidad étnica (Feltham 2005). Creemos que esta afirmación etnohistoricista, 
es apresurada debido a una descuidada interpretación del documento colonial, y que lo que antes se había pensado como una sola identidad étnica Yauyu, siguiendo los datos históricos, podría ser en realidad una consecuencia de la intervención estatal Inca en la sierra de Lima.

Partamos revisando lo que nos dice el ya muy recurrido Dávila Briceño: "Esta dicha provincia de Yauyos tomo nombre de unos pueblos que hay en ella que ansi se llaman, que hoy están encomendados en la Real Corona; y por ser gente belicosa estos dichos Yauyos, y ser gente belicosa (así) y se servir de ellos los Ingas en todas sus guerras, se llamó toda esta provincia Yauyos, aunque estos Yauyos era poca gente y estaban poblados en cuatro pueblezuelos, que yo reduje en uno que se llama Santo Domingo de Atun Yauyo. Serán hasta trescientos $y$ cincuenta indios tributarios. $Y$ por estos, como dicho es, tiene toda esta provincia nombre de Yauyos, aunque cada guaranga o parcialidad de toda ella tienen diversos nombres; $y$ en general, por la causa dicha, se llaman Yauyos" (Jiménez de la Espada 1965).

La cita es explícita. El espacio geográfico habitado por los pueblos prehispánicos de las provincias actuales de Huarochirí y Yauyos, en tiempos de los inkas, fue llamado Yauyu o Yauyo a raíz de la importancia que tuviera un pequeño grupo comunitario del mismo nombre, en las guerras de expansión emprendidas por el emergente estado qosqeño. Este grupo originario Yauyu, como lo señala el documento estaba formado solo por cuatro pueblos que posteriormente Dávila redujo en Santo Domingo de Atun Yauyo. Dos interpretaciones nos viene al revisar este pasaje: 1) es con los inkas que se especifica esta denominación general para los pueblos de la sierra de Lima, es posible que antes de la presencia qosqeña, en el gran territorio de las provincias de Huarochirí y Yauyos no haya habido un grupo hegemónico y homogéneo distribuido sobre las tierras de este espacio geográfico, más bien como lo señala el documento, habrían una gran cantidad de pueblos esparcidos. 2) Esta denominación es otorgada como un reconocimiento al aporte de una determinada comunidad al servicio estatal. La ausencia de un grupo hegemónico y homogéneo, hace por ende plausible y necesario el reordenamiento inka, y la ascendencia de los Yauyu como el grupo comunal referente de la sierra limeña que estaría ligado precisamente al papel que este jugo en los planes de expansión y control del estado inca. Al respecto de esto último el Manuscrito quechua de Huarochirí (Taylor 1987) nos dice:

"Capítulo 23:

36. "Padre Macahuisa", le dijo [a la huaca victorioso] "¿Qué voy a darte? Pide lo que quieras. No seré avaro". El otro le respondió: "yo no deseo nada excepto que te hagas huacsa [y celebres mi culto] como lo hacen nuestros hijos Yauyos". El inga acepto [pero] temiendo mucho quiso ofrecerle todo lo que pudiera para que no lo aniquilara a él también."

Es interesante notar aquí la relación que existe entre los Yauyu y el culto a Macahuisa. Macahuisa como se registra en el Manuscrito, es el camac que alcanza gran prestigio, seguramente debido a sus hazañas y servicio para el estado inka, de esta manera Pariaqaqa justifica su importancia y renueva el prestigio de su culto a través de su hijo Macahuisa en tiempos de Topa Yupanqui. Macahuisa es el hijo de Pariaqaqa surgido en tiempos en que la administración de la región de Huarochirí y Yauyos se encuentra bajo la tutela Yauyu. Podemos decir por ende que se trata del más notorio representante de los aportes e intereses de la etnia Yauyu.

Ahora bien, estas interpretaciones nos plantean un problema de base ¿Cuál es el criterio de reordenamiento, y sobre todo justificador que permite favorecer a un grupo comunal sobre los otros muy diversos? Mas allá de recompensar merecidamente los servicios de un grupo comunal, es posible que haya habido descontento con el proceder inkaico entre los demás y muchos pueblos de Huarochirí y el propio Yauyos al verse agrupados bajo un orden reciente. El gran éxito de este reordenamiento estatal inka, sugiere que el descontento no fue de las dimensiones como para truncar esta medida. 
Este ha de deberse a tres puntuales fundamentos:

Primero, Dávila Briceño nos refiere el panorama conflictivo en el que se encontraban los numerosos pueblos de la sierra limeña prehispánica con sus vecinos: “... estando poblados de antes en más de doscientos pueblos pequeños, en riscos y punas de cierras/sierras/y lugares fuertes, a causa de las guerras questa provincia tenia, antes que la conquistasen españoles, con los Yungas de los llanos de la costa de la mar del Sur, que le caen a la parte del Occidente, do esta la famosa ciudad de Los Reyes; y con la provincia de los Chocorbos, que le caen (así) a la parte del Sur; y con los Guancas de la provincia de Xauxa y Tarama, que le caen al Oriente; y con la provincia de los Atauillos, de Canta, que le caen (así) al Norte; porque con todas estas dic has provincias tenían guerras en su gentilidad. -- Todas las provincias dichas que cercan a esta de Yauyos, y esta también, hablan lenguas diferentes unas de otras; aunque la gente prencipal de todas ellas hablan la lengua general de los Ingas, senores que mandaron esta tierra" (Jiménez de la Espada 1965). Sería el constante sentido de convivencia conflictiva en que se encontraban con sus vecinos lo que permitió a estos muchos pueblos organizarse bajo un frente común, para sostener su posición sobre el espacio geográfico ocupado.

Segundo y según nos cuenta el Manuscrito quechua de Huarochirí (Taylor 1987):

"Capitulo18:

3. "Ise dice que/ fue el inga también quien ordeno a treinta [hombre] de Hanan Yauyo y de Rurin Yauyo servir a Pariacaca en la época de la luna llena."

La reorganización estatal inka no agrupó rigurosamente a estos pueblos en un solo gran territorio administrativo. Siguiendo los principios andinos, se reorganizó a éstos pueblos en Hurin y Hanan. En otras palabras en una dualidad provincial, con Huarochirí en el frente norte y Yauyu en el frente sur.

Tercero, y fundamento más importante, según los documentos etnohistóricos de los siglos XVIXVII, estos pueblos estarían vinculados entre sí por lazos de hermandad, debido al culto a un mismo camac, el Apu Pariaqaqa, como bien se ha señalado anteriormente. Este sería sin duda el fundamento que permite la reorganización. Además está claro, que probablemente el origen de este camac se encuentre en la tradición mítica de Yauyos antes que Huarochirí. Lo cual otorga cierta paternidad a la administración Yauyu del culto de este Apu.

No obstante de estos fundamentos, y además de estar constituido por comunidades descendientes de un mismo culto, la llamada etnia Yauyu, estaba conformada además de otros grupos comunitarios de origen no serrano, como el caso de los yungas costeros, a los llacuaz de las punas a los que generalmente en el mito llama extranjeros ${ }^{6}$ (Taylor 1987), pero que no obstante también mantienen filiaciones sociales de complementariedad auspiciados por el culto a Pariaqaqa. Por lo cual, habría que decir que la manera de justificar tal etnicidad es incidiendo en un sentido de adscripción de identidad comunitaria en base al culto compartido de un camac regional, el cual sería Pariaqaqa, lo cual estaría permitiendo a estos pueblos organizarse para enfrentar a sus vecinos Canta, Atavillos, Ychsma, Guancas, Xauxas, Tarmas, Caranges, y otros.

No obstante a esta participación común de un mismo culto regional, al interior de los espacios territoriales los datos etnohistóricos señalan un marcado conflicto de identidades comunales: los términos "advenedizo", “extranjero", los “diminutivos" despectivos son empleados por las comunidades

6. Hernán Amat bien ha señalado la importancia de estos pastores y o extranjeros, denominados yaros, en la escena histórica de la sierra de lima (ver Amat 1992) 
como expresiones que buscan diferenciarlas de los otros grupos comunitarios. En ella es claro que los grupos serranos checa intentan distinguirse de los demás pueblos yungas y llacuaz con los cuales comparte el territorio, así como de sus vecinos de más al Sur, los Yauyu. Veamos al respecto la presencia de los Yauyu en el manuscrito quechua de Huarochirí (Taylor 1987):

"Capitulo24:

11. los demás cacasica y morales, así como los antepasados de los canchaypaycu, eran yauyos.

12. su lugar de origen se llama Maurura [y se encuentra] en la dirección de Ayahuire.

13. estos [Yauyos], vagando como nómades, se casaron con las hermanas de los huarcancha y, como deseaban establecerse en las tierras de sus cuñados y mantener relaciones armoniosas con estos, se quedaron en este país.

14. cuando iban a adorar a Pariacaca, -como sus cuñados y todos los checa los despreciaban llamándolos: "Yauyos vagabundos"- seguían siempre a los demás quedándose, muy lejos, atrás.

15. sufrían muchos ese desprecio y, durante muchos años, iban siempre detrás [de los otros].

16. una vez, le contaron a Pariacaca diciéndole: "padre, estos [nuestros cuñados] y los checa nos tratan con mucho desprecio; somos animados por ti aunque seamos Yauyos". Y, al contárselo, lloraban mucho.

17. entonces, [Pariacaca] les dijo: "hijos, jno estéis triste! Llevad este chunculla de oro; llevándolo en las manos bailareis en el lugar llamado Pococaya en Llacsatambo. Cualquier hombre, [que vea eso,] os veneraran mucho por ser tan queridos por Pariacaca. Entonces ya no os despreciaran tanto". Con estas palabras, prescribió [su suerte].

18. entonces, cuando estos Yauyos llegaron detrás de todos los checa, llevando el chunculla de oro con gran regocijo, los demás hombres los veneraron.

19. al día siguiente, bailaron en la pampa llevando el chunculla de oro, venerados por todos.

20. otros cuentan que, /según la tradición, / en los tiempos muy antiguos, [la gente] solía hablar con Pariacaca de noche, ofrendándole llamas y otras cosas.

21. cada ayllu iba [a adorarlo] por turno.

22. [una vez,] aun hablando con gran desprecio, decidieron que los nómades Yauyos también deberían llevarle [sus ofrendas]."

Estos pasajes exponen el origen extranjero de los Yauyu en la región de Ayaviri, y como estos se emparentaron con los huarcancha, y tuvieron descendencia en los ayllu Canchapaycu. No obstante la situación de los Yauyu en Huarochirí no es mejor que el de los yungas. Tratados como nómades, extranjeros, fueron despreciados por sus cuñados por querer asentarse en sus tierras, incluso dentro de las ceremonias y rituales en favor de Pariaqaqa el Apu de prestigio regional, ocupan una posición marginal, detrás de los checa. Pienso que esta situación se da ya desde tiempos anteriores a la presencia inkaica en la costa central. Ya en tiempos del Tawantinsuyu, los Yauyus debieron terminar por ocupar una creciente posición al hacerse de los emblemas del culto a Pariaqaqa, auspiciados por el régimen inka, como narra el pasaje, hasta que finalmente son aceptados pero "aun con desprecio" para oficiar el culto a Pariaqaqa. El manuscrito quechua agrega a la discusión (Taylor 1987):

\section{"Capítulo 31:}


Bradymir Bravo / La distribucion y organización del territorio de los huarochiri prehispanicos...

habían ido por aquellas partes.

53. /se dice que, / en [la laguna de] Yansa había un huaca de nombre Collquiri.

54. Por servir [llacsamisa] a estas huacas] (¿Yansa y Collquiri?), cada año todos los concha se esforzaban en cultivar maíz para alimentarlos...

55. en aquella época, Collquiri deseaba mucho [tener] una mujer.

56. así que fue hasta Yauyos y hasta Chaclla buscándola por todos partes.

57. pero no la encontró.

153. cuando [el mismo] estuvo a punto de morir, sus sobrinos, los hijos de Hualla, de vuelta de los Yauyos, se casaron con las hijas de Cunocuyo -el padre de estas se llamaba Yasali."

Aquí se narra las incursiones de los pueblos huarochiranos en la región de Yauyu. Nuevamente se habla de los Yauyus como un grupo comunitario establecido en un lugar en específico, más allá de las sierras de Huarochirí. Como se ha dé notar de la cita, Collquiri héroe mítico huarochirano busca una mujer en tierras más sureñas, en Yauyos, y en tierras más hacia el norte en Chaclla. Entendamos esta búsqueda en términos de alianzas entre las comunidades, y como los esfuerzos del héroe mítico por fortalecer la expansión de su ayllu o comunidad. Collquiri no encuentra una mujer ni puede establecer alianzas para su comunidad, sin embargo sus sobrinos hijos de los Hualla, probablemente resultantes de otras alianzas comunitarias, volviendo de la región de Yauyu a donde habían ido encuentran alianzas matrimoniales con los Cunocuyo.

De este pasaje, agregando a la cita líneas más atrás del capítulo 24 del Manuscrito: 12. "su lugar de origen se llama Maurura [y se encuentra] de en la dirección Ayahuire". Podemos posicionar a los Yauyu en un espacio geográfico más o menos establecido y como un grupo comunitario definido en esa posición territorial en la cuenca del río Cañete. Como tal su carácter foráneo es remarcado en el panorama de Huarochirí, y por ende la necesidad de emparentarse con los ayllu locales para ocupar las tierras de dicha provincia. Al referirse a las infructuosas negociaciones de alianza entre estos Yauyu y los de Collquiri, evidencia que los grupos comunitarios del sur, Yauyos, y del norte, Huarochirí, son grupos de identidades comunitarias diferenciadas y posiblemente en conflicto y competencia.

"Suplemento 2:

22. Eso es todo lo que sabemos sobre estos checa de San Damián.

23. es probable que en otras comunidades cuenten [tradiciones] diferentes.

24. Sin embrago, cuando nace un ata, en todo este corregimiento y en todas las otras regiones, los huanca, los yauyo, los huamantanca, cualquiera de los hombres indios, todos opinan la misma cosa".

Finalmente en el suplemento se revisa el caso de los niños sacros, ata, curi, e illa, de los Checa, registrando su caso de forma independiente, aunque con discurso compartido, de los demás grupos regionales, incluido el de los Yauyu.

Los indicios anteriormente citados, nos inducen a pensar que en tiempos anteriores al Tawantinsuyu, los pueblos de Huarochirí y Yauyos no componían una identidad étnica, se encontraban divididos en diversos grupos comunitarios, cuyos vínculos están sostenidos por el culto a Pariaqaqa. Incluso con la presencia administrativa inka, los Yauyu no fueron bien recibidos aunque si soportados, en la escena huarochirana, seguramente más por temor a los inkas, mediadores y auspiciadores de los Yauyu. Posiblemente una de las formas de intervención inkaica en la sierra de Huarochirí, haya 
tenido que ver con la introducción de ayllus Yauyu en las comunidades locales de Huarochirí, ya sean estos como mitmas o yanas al servicio del estado. Posiblemente este sería el origen del actual pueblo de Tupicocha, mencionado ya por Ávila en el Manuscrito (Taylor 1987). La toponimia de este pueblo, se presta a interpretaciones con respecto a pueblo de Tupe en el corazón de Yauyos, desde donde posiblemente habrían venido los ayllus que fundaron dicho pueblo más abajo de San Damián de los Checa hacia la vertiente del Rímac.

En todo caso no es posible hablar de grupo étnico homogéneo en la sierra de Lima, ya que tal etnicidad parece sustentarse a una adscripción a una identidad religiosa común, que estaría sustentado en el culto a un mismo camac de trascendencia regional. Si aceptamos esto, lo que se ha venido a definir como una expansión Yauyu en la sierra de Lima en realidad sería la expansión del culto a Pariaqa$q a$, auspiciada por diversos grupos comunitarios (como los checa) al mando de un héroe mítico al que se considera como hijo suyo (como sucede con Tutayquire o Macahuisa), y en su momento, auspiciados por la administración estatal inka. En los capítulos siguientes desarrollaremos la argumentación para sostener esta tentativa.

Ahora bien debemos aclarar que el supuesto panorama explicado, sería aquel que el extirpador de idolatrías habría encontrado después de la reorganización del espacio de la sierra de Lima por los inkas, por lo que el panorama anterior a este momento, es decir durante gran parte del Intermedio Tardío no está claro, y es difícil precisar con seguridad hasta donde el valor de los documentos etnohistóricos no sirven para extrapolar la interpretación a los periodos tardíos. Además, está el delicado asunto de hasta qué punto el discurso legado en los documentos históricos estaría condicionado por la presencia supresora y castigadora de la cristiandad hispana. No obstante de enfrentarnos con estos problemas, en este ensayo se correrá dicho riesgo, pues consideramos que al menos el Manuscrito Quechua de Huarochirí guarda la suficiente información como para alcanzar a definir algunas pautas diferenciales y características de dicho panorama en los momentos anteriores a la anexión de la sierra limeña por parte de los inkas.

\section{Los "Héroes míticos-PACARINAS o Fundadores" de Huarochiri: UN CASO DE ORGANIZACIÓN Y DISTRIBUCION DEL ESPACIO EN BASE AL CULTO.}

\section{LOS MACHOS DEL MITO}

En la mitología de Huarochirí, el nombre de los personajes míticos y sus acciones, figuran en la historia para marcar un comienzo y el fin de una época. Las acciones que producen estos personajes míticos, tiene precisamente su razón de ser, en producir la acción que apertura un nuevo orden y finaliza uno anterior (Ortiz 1993: 151). Las circunstancias implicadas con cada personaje se imponen al personaje. Son por ende como lo dice Ortiz, hitos y emblemas, que apertura un nuevo orden y definen las características de ese nuevo orden. Siguiendo este principio, en el Manuscrito Quechua de Huarochirí, la presencia de los personajes míticos indica un momento temporal y representan las características de este momento.

Cuatro personajes míticos serían los demarcadores temporales mayores en el mito huarochirano, se tratan de camac cuya trascendencia en la vida de los pueblos prehispánicos parece tener dimensiones regionales: Tutañamca Yanañamca, Huallallo Carhuincho, Pariaqaqa, Cuniraya Wiraqocha (Arroyo 2006, Taylor 1987). Cada personaje apertura un nuevo orden y cierra otro, la forma en que desencadena este nuevo orden define las características de su naturaleza. Es decir, las circunstancias en las cuales surge 
el nuevo orden al momento de romper con el orden antiguo vienen a llamarse Tutañamca Yanañamca, Huallallo Carhuincho, Pariaqaqa, Cuniraya Wiraqocha. Estos nombres por tanto no se refieren solamente a las características de un personaje específico, sino también a las circunstancias de un tiempo ${ }^{7}$.

1) Tutañamca Yanañamca. Momento de origen local. Indica las circunstancias de un tiempo de oscuridad.

2) Huallallo Carhuincho. Momento venido de la sierra central. Apertura un nuevo orden al vencer a Tutañamca Yanañamca. Indica las circunstancias de un tiempo de fertilidad, extrema densidad demográfica, y rituales de sacrificio humano (Arroyo 2006, Taylor 1987). Momento de constantes guerras entre los pueblos y sus camac (Tello y Miranda 1923).

3) Pariaqaqa. Momento de origen local. Apertura un nuevo orden al vencer a Huallallo Carhuincho. Indica el tiempo de la conquista de los pueblos serranos sobre los yungas.

4) Cuniraya Wiraqocha. Momento de origen foráneo o inka (Arroyo 2006). Indica las circunstancias del reordenamiento de los pueblos de la costa central por los inkas. Convivencia del culto local y el inkaico.

Finalmente habrá que agregar aquí a Macahuisa como resultado del surgimiento de los tiempos de convivencia de Pariaqaqa y el culto inka. Como el camac surgido de las expectativas de la administración inca en la provincia de Hatun Yauyu, y como el ejemplo del culto que sobrevive a la desintegración del culto a Pariaqaqa en tiempos de los españoles.

La anterior temporalidad de los camac, nos sugiere: 1) A cada momento y orden local le sucede un momento y orden de origen extranjero (el arribo de Huallallo, el arribo de Cuniraya). 2) Los momentos y órdenes se suceden en un contexto de enfrentamiento entre los camac, salvo el último momento donde el arribo de Cuniraya no implica la derrota de Pariaqaqa, esto estaría sugiriendo la anexión, no tanto pacífica, pero si negociada de los Huarochirí y Yauyu al estado inka. No obstante si se hace notar el agravio inka en la costa central, sino recordemos que Cuniraya aparece humillando a las huacas locales, tomando con artimañas a sus mujeres, como sucede con Cahuillaca, o en otros casos violándolas como sucede con las hijas de Hurpayhuachac (Taylor 1987). 3) Al menos a los dos primeros momentos y gran parte de tiempo de Pariaqaqa podemos ubicarlo, según nos dice el Manuscrito, en los tiempos de purum pacha (C5: 2-6) . Aquí debemos distinguir dos momentos: a) Purum Pacha como tiempos de origen oscuridad y caos ${ }^{9}$, asociado a Tutañamca Yanañamca, y b) purum pacha como tiempo donde los hombres solo se dedicaban a guerrear y luchar entre sí (C5:3), y reconocían como curacas solo a los valientes y a los ricos (C5:5), asociado a Huallallo y Pariaqaqa.

7. Ha de notarse al respecto, que estos camac no parecen tratarse de personajes específicos, sus nombres mismos indican multi-componentes de posibles personajes. Tutañamca Yanañamca, son en realidad dos, Pariaqaqa sería en realidad cinco nacidos de un huevo (Taylor 1985, Ortiz 1993).

8. En este trabajo será común encontrarse las citas referidas a los capítulos del Manuscrito (abreviamos de Manuscrito Quechua de Huarochirí) la siguiente forma de apertura: $\mathrm{C}$ 1:3. Aquí, "C" representa la abreviatura del termino capitulo, " 1 " viene a ser el número de capitulo que se está citando, y ":3" viene a ser el número de ítem dentro de capitulo que se está citando. Se procede de este modo para no confundir con las numeraciones del ítem de los capítulos del Manuscrito Quechua de Huarochirí. La versión tomada del documento del padre F. Ávila es la de G. Taylor de 1987.

9. Época de caos y oscuridad para Betanzos, Santa Cruz Pachacutic, y Guamán Poma. Para Santa Cruz de Pachacutic también se refiere a una época de origen u oscuridad. 
Cabe señalar, que los personajes míticos como demarcadores temporales de apertura o cierre de un momento y orden, se suceden a nivel estructural. Es decir, pueden haber personajes míticos que demarquen la temporalidad en términos regionales como los personajes expuestos anteriormente, y hay otros que a dimensiones más pequeñas o locales también inauguran y cierran un momento y orden, como sucede con los camac "héroe mítico-paqarina o fundador".

En los párrafos siguientes nos proponemos a analizar la distribución y organización del territorio o espacio en base al culto a los "héroes míticos-paqarina o fundador" durante el cierre del momento y orden de tiempo de Huallallo y la apertura al momento y orden del tiempo de Pariaqaqa.

Después de la victoria de Pariaqaqa sobre Huallallo Carhuincho en su enfrentamiento de Mullucocha, F. Ávila narra:

"Capitulo 16:

9. también señalamos que Huallallo Carhuincho /, según dicen, / no huyo enseguida.

10. cuando uno de los [que nacieron con] Pariacaca, Chupara ${ }^{10}$, entro en [el territorio que hoy se llama] Mullococha y lo trasformo en laguna, Huallallo, convertido en pájaro, alzo el vuelo [y huyo] de allí.

11. Luego entro en un cerro llamado Caquiyoca.

12. /se dice que/ este cerro [era] una peña enorme.

13. Huallallo Carhuincho se escondió allí.

14. Entonces, Pariacaca con los demás cinco hermanos, casi arrasaron la peña con sus rayos y de nuevo ahuyentaron a Huallallo Carhuincho.

15. Este hizo surgir una serpiente enorme llamada amaru, un amaru de dos cabezas, para que fuera nefasto a Pariacaca.

16. al verlo, Pariacaca se puso furiosos y clavo un bastón de oro en medio de su lomo.

17. en el mismo instante, el amaru se convirtió en piedra.

18. /se dice que, / aun hoy se puede ver a este amaru petrificado en el camino llamado de Caquiyoca de Arriba.

20. Huallallo Carhuincho, huyendo de la peña de Caquiyoca, entró en una quebrada llamada Caquiyocahuayqui.

21. Entonces subió a un cerro nombrado Pumarauca; allí hizo surgir a un loro llamado caque y lo hizo amenazar a Pariacaca con sus alas apuntadas como lanzas pensando que así iba a crear una barrera para impedir que Pariacaca pasara más allá.

22. sin esfuerzo, Pariacaca le quebró un ala y convirtió el caque en piedra; así le venció [a Huallallo].

23. como Huallallo Carhuincho quedo completamente sin fuerza alguna, huyó hacia [la región de] los antis.

10. N.M. en quechua= "/se dice que/ su nombre era Sullca Illapa" 
Bradymir Bravo / La distribucion y organización del territorio de los huarochiri prehispanicos...

24. Pariacaca, junto con todos sus hermanos, lo persiguió.

25. Como [Huallallo] ya había entrado en [el territorio de] los antis, [Pariacaca] dejó a uno de sus hermanos nombrado Pariacarco en la puerta de los antis para impedirle volver.

26. /dicen que/ ese Pariacarco aún permanece allí [en forma de] un gran nevado.

27. no sabemos quiénes adoran a [Huallallo Carhuincho].

28. pero, en el noveno capitulo, ya narramos lo dicho [por Pariacaca]: "por haber comido a los hombres ique los huacas le den de comer!."

(Taylor 1987: 259-265).

En este episodio se narra la resistencia de Huallallo Carhuincho después de su primer encuentro con los hermanos Pariaqaqa. Si bien, este episodio mítico se circunscribe en el escenario de las alturas de Mullococha de Huarochirí, bien señala que la expulsión del culto al "devorador de hombres" no sucedió de inmediato, sino supuso un periodo de constantes encuentros y enfrentamientos, mientras diezmaba la resistencia de los adoradores de Huallallo en las sierras de Huarochirí. Tal parece que es en este contexto en que J. C. Tello propone a San Pedro de Casta y la meseta de Marka Wasi como el último reducto de Huallallo Carhuincho (Tello y Miranda 1923: 510, Carcelén 1996: 99-101).

Desde su reducto en Marka Wasi, Huallallo mantenía luchas continuas con el emergente camac de los Huarochirí, Pariaqaqa, y con los camac locales Wampu y Makas (Tello y Miranda 1923: 513). En uno de los pasajes de su obra Tello y Miranda nos cuentan las rencillas con el camac de los Carampoma y Huanza, Wampu:

"Wampu estaba envidioso de las florestas de keñuales, linkos, chachakomas, llokes, pupas y de los pajonales que embellecían y constituían la riqueza de la morada de Wallallo en Marka Wasi. Se propuso, instigado por sus súbditos, arrojarlo de sus dominios y arrebatarle todas sus riquezas. Para ello se preparó durante mucho tiempo; se fortaleció todas sus riquezas. Se fortaleció bebiendo grandes cantidades de sangre humana que gustoso les prodigaba los suyos; le tendió a Wallallo varias celadas, en todas las que fracasó: al fin, conociendo que una de sus mujeres era perseguida tenazmente por los requerimientos amorosos de Wallallo por los requerimientos amorosos de Wallallo, le aconsejó que aparentara dejarse seducir, y que en el instante en que Wallallo pretendiera finalizar sus intenciones, le arrancara los testículos y gritara a fin de que él y todos los indios acudieran en su auxilio. El astuto Wampu desarrolló su plan con la mayor inteligencia y exactitud. Logrando que Wallallo perdiera, al pretender escapar -como solía en otras ocasiones, de la celada tendida por su enemigo- el órgano que le decapitaba para procrear mellizos y para fertilizar las tierras. Fue tal la alharaca que hicieron Wampu y los suyos, a la señal de la diosa; fueron tantos los truenos, rayos, granizo y lluvia que arrojaron al mismo tiempo todos los dioses contra Wallallo; fue tal la precipitación con que escapara de la celada, que no se dio cuenta al regresar a Marka Wasi, que había perdido uno de sus más importantes atributos.

Wampu escondió el órgano seminal de Wallallo en la cueva de Kankausho que se hallaba cerca de Marka Wasi (...) poco tiempo después paso, paso por alli un yachik del Titikaka... De modo casual fue a descansar,..., en la cueva donde Wampu había escondido el dídimo (...) Creyó que había encontrado un objeto mediante el cual podría realizar hechos maravillosos (...) volvió precipitadamente al Kollao para mostrarles a los yachik de esa región su precioso hallazgo (...) Wallallo se daba cuenta que su poder de procrear se había anulado; que sus fuerzas disminuían, y al fin notó la desaparición del órgano que Wampu le había arrebatado. La diosa que sirvió a Wampu para realizar su malévolo propósito, vivía celosa de otra a quien Wallallo también perseguía con sus requerimientos amorosos; tratando de desacreditar a Wallallo, le refirió a aquella lo que esta divinidad había perdido; y la diosa comunicó la noticia a Wallallo. Él supo (...), que un yachik del Kollao se lo había llevado. Salió en su persecución transformándose en humano. 
La desaparición de Wallallo fue la ruina de todos sus súbditos; las tierras se hicieron estériles; (...) todo desapareció por la rapacidad de Wampu que la hizo trasladar a su propia región.” (Tello y Miranda 1923:515-516) En el Manuscrito Quechua de Huarochirí se menciona a un Chuquihuampo como hijo de Pariaqaqa que ayudó a su padre a combatir a Manañamca o Mamañamca, la mujer de Huallallo Carhuincho. Veamos lo que se dice de el:

\section{"Capitulo 8:}

41. Manañamca también [luchaba en forma de] fuego.

42. Pariacaca, entrando por la parte baja de Tumna, se enfrentó con ella.

43. [Manañamca], arrojado [sus llamas] desde abajo, alcanzó a uno de los hijos de Pariacaca llamado Chuquihuampo en el pie.

44. sin embrago, fue de nuevo Pariacaca quien venció, y la ahuyentó hacia la laguna.

45. cuando ya había vencido a estos, volvió al sitio donde se encontraba su hijo Chuquihuampo, quien, al quebrarse el pie, se había quedado cojo.

46. este le dijo: "no regresaré; voy a quedarme aquí para custodiar de cerca a esta mujer, Manañamca, e impedir que vuelva". Su padre estuvo de acuerdo y prescribió todo lo que iba a recibir como ofrendas.

(Taylor 1987: 157).

Aunque lo que se dice de este hijo de Pariaqaqa parece no tener relación con el Wampu de los Carampoma y Huanza, debido al espacio donde suceden las acciones del mito, ambos se encuentran relacionados al momento del enfrentamiento con Huallallo Carhuincho. Wampu lo enfrenta directamente; mientras Chuquihuampo combate con su mujer, a diferencia de otros hijos de Pariaqaqa que no llegan a enfrentar a esta pareja de camac, como sucede con Chucpayco, Chancharuna, Huariruna, Utcochuco, Tutayquire, Sasenmale, o Pachachuyro. Chuquihuampo está relacionado, al igual que Huatyacuri, al momento de las hazañas de Pariaqaqa y sus hermanos. Por ahora es difícil proponer que el Wampu de los Carampoma y Huanza está vinculado o se refiere al Chuquihuampo hijo de Pariaqaqa. No obstante no está demás mantener abierta la posibilidad.

Se ha propuesto que el norte huarochirano, aquel que se encuentra con las tierras de Canta, estaba dominado por los grupos Yauyus de Carampoma en la parte alta de la cuenca de Santa Eulalia, y los de Chaclla ubicados entre la cuenca de Santa Eulalia, y el valle de Chillón, más abajo que los anteriores (Rostoworowski 1978; 2002: 210, 212). Se desconocen los fundamentos para asumir que los Carampoma hayan sido Yauyus. Si bien, como lo documenta Tello y Miranda, estos se encuentran enfrentados con los adoradores de Huallallo Carhuincho, no se sostiene su relación con Pariaqaqa, salvo como dicen los autores, que se cree que estos camac de la fertilidad están relacionados con el rayo: "el rayo llamase Wallallo, Wampu, Makas o Yaro" (Tello y Miranda 1923: 511). Ante la irrupción del culto al "devorador de hombres" entre los Carampoma y Huanza, con las aspiraciones de Huallallo por congeniar con la huaca local, que se dice es [o será] mujer de Wampu, estos pueblos emprenden sus luchas contra los de Marka Wasi y su camac Huallallo, amparados en la tutela de Wampu, quien logra finalmente por intermedio de la huaca local, vencer y expulsar a Huallallo. Es claro entonces que los Carampoma y Huanza, se encuentran amparados bajo el culto a Wampu, vencedor de Huallallo, y no precisamente bajo el culto a Pariaqaqa. Aunque se supusiera una relación entre Chuquihuampo y Wampu, y tal vez el verlos como el mismo personaje mítico, es más sostenible que los Carampoma y Huanza hayan antepuesto el culto a su héroe mítico sobre el culto de cualquier otro camac. Si bien es cierto es posible que tras la huida de los adoradores de Huallallo, los cultos a Wampu y Pariaqaqa se hayan encon- 
trado, y que el prestigio de Pariaqaqa le valiera ser considerado en estimaciones por los Carampoma y Huanza, y que los inkas hayan determinado las provincias de Huarochirí y Yauyos como dominio de los Yauyus, no es posible decir que los Carampoma-Huanza hayan preferido el culto a Pariaqaqa por encima del culto a su héroe mítico local y camac Wampu.

Sabino Arroyo (2006: 45) relaciona a Wampu con los pueblos de la comunidad de los Chaclla. según el litigio de 1559 presentado en la Audiencia de los Reyes, Justicia 413, del Archivo General de las Indias, que diera a conocer M. Rostoworowski, donde se reporta la disputa entre los yungas Collí (valle bajo del Chillón), y los pueblos serranos de Canta (valle alto del Chillón) y los de Chaclla (valle alto de Santa Eulalia), que reclamaban para sí las tierras cálidas (chaupiyunga) de Santa Rosa de Quives (Rostoworowski 1978), Chaclla se entendía como una subdivisión de los Yauyu supeditado a la provincia de Huarochirí. La relación entre Chaclla y la etnia Yauyu ha sido muy insistente a partir de la reducción de Dávila Briceño del territorio Yauyu en 5 repartimientos: Mancos y Laraos, Atun Yauyus, Huarochirí, Alto Rímac hasta San Mateo de Huanchor, y Chaclla (Rostoworowski 1977, 1978; Carcelén 1996; Gentille 1976, 1977; Bazán 1990).

Vale señalar que uno de los asentamientos que compone el espacio arqueológico de Chaclla en la margen derecha de la sierra, ya muy alejado de la cuenca de Santa Eulalia, se llama Huampo. Aquello parece coincidir con lo afirmado por Arroyo. Podemos especular que después de valer en el enfrentamiento de su padre contra Chaupiñamca, Chuquihuampo o los de su culto, emprendió la marcha sobre esas tierras. Desde este nuevo frente Chuquihuampo habría enfrentado a Huallallo que estaba fortalecido en San Pedro de Casta. Esto parece coincidir con lo señalado por Tello y Miranda, que este se encontraba en enfrentamientos con los camac locales Wampu y Makas. Aunque no es muy difícil asegurar que Wampu y Makas sean camac locales de un mismo grupo de pueblos asentados en un espacio más o menos definido (como comúnmente podría suceder en el territorio andino donde la dualidad es un principio incluso entre la organización de sus camac), cabe la posibilidad que Makas tenga su propio espacio de culto definido independientemente del de Wampu. Desde Chaclla, Chuquihuampo habría enfrentado sin éxito a Huallallo, fortalecido en su fuerte de Marka Wasi. Dentro de sus tantas estrategias para derrotarlo habría estado la de establecer lazos de parentesco con los Huanza y Carampoma, también reacios a Huallallo, por medio del matrimonio con su huaca local. Huallallo Carhuincho conciente de su difícil situación, ha sido expulsado de Huarochirí y su antiguo adoratorio en Mullucocha, y se halla amenazado constantemente por Makas y Wampu, intenta también la muy usada estrategia, ve en el matrimonio con las huacas locales un medio de expandir sus lazos de relaciones con los pueblos locales y establecer filiaciones de parentesco. Se ha mencionado ya las muchas mujeres que habría tenido, estas probablemente de diferentes comunidades, como lo era Mamañamca de Mama. Huallallo corteja insistentemente a la huaca de los Huanza y Carampoma, que ya habría sido prometida a Chuquihuampo de los Chaclla. Este aprovecha la tardía reacción y necesidad de Huallallo, y prepara con sus futuros aliados la ya contada treta que hace caer en desprestigio a Huallallo, que al quedarse inútil e infértil pierde el apoyo de sus mujeres huacas y la de sus pueblos, por lo cual termina por ir en busca de sus órganos genitales. Chuquihuampo victorioso entonces habría sido recibido como Wampu entre los Huanza y Carampoma. La posterior presencia de Soqta Qory, reminiscencia de Huallallo entre los de Casta (Arroyo 2006: 45) habría impedido la unión de todo ese frente. Interponiéndose como una gran isla entre los dos cultos a Wampu debido a lo muy arraigado que estaba el culto a Huallallo entre los de Casta. Esto ha de deberse también como lo narran Tello y Miranda, a que Wampu solo estaba interesado en saquear y apropiarse de los productos de la tierra de Marka Wuasi.

Ahora bien, pese a esta adornada interpretación que se ha realizado, siempre por ahora será mejor considerar la relación entre Chuquihuampo y Wampu como especulativa, no obstante no ha de descar- 
tarse. En todo caso tanto el Wampu de los Chaclla y el de los Huanza y Carampoma parecen guardar relación con el tipo de camac "héroe mítico-paqarina o fundador". El Wampu de los Chaclla, es camac y fundador de esta comunidad, y el Wampu o Chuquihuampo también sería héroe mítico; por otro lado el de los Huanza y Carampoma es también héroe mítico, camac, y ancestro.

Según el Manuscrito quechua de Huarochirí, los checa conformaban el quinto de los siete grupos descendientes de los hijos de Pariaqaqa, cuyo héroe fundador sería Tutayquire (Salomon 1997: 243). Rostoworowski señala los restantes hijos de Pariaqaqa: Huariruna, Chancharuna, Chucpayco, Huarquinri, Utcochuco, Pachacayro, y Are male. Según la autora los pueblos de la sierra limeña se identificaban fuertemente con alguno de estos hijos de Pariaqaqa (Rostoworowski 2002: 209).

Según el Manuscrito el número de hijos de Pariaqaqa es aún mayor:

[Hijos relacionados a la apertura del momento y orden del tiempo de Pariaqaqa]

- Huatyacuri

- Chuquihuampo

[Hijos relacionados al tiempo de Pariaqaqa]

- Chucpayco

- Chancharuna

- Huariruna

- Utcochuco

- Tutayquire

- Sasenmale

- Pachachuyro

[Hijos relacionados al tiempo de convivencia del culto a Pariaqaqa y el poder inka]

- Macahuisa

El Manuscrito, nos menciona a Tutayquire, héroe mítico de los checa y los concha, que habrían ocupado las tierras de San Damián, San Bartolomé de Suquiacancha, Cocachacra, Carachacra (Rostoworowski 2002: 211), Santiago de Tuna, San Andrés de Tupicocha, y habría emprendido la conquista de los valles medios del Rímac y Lurín:

"Capitulo 11:

6. /sabemos qué/ Tutayquire era hijo de Pariacaca.

7. se dice que en tiempos antiguos, los checa también eran quinti, eran los hermanos menores de los quinti.

8. los quinti despreciaban mucho a los checa por haber nacido después [de ellos].

9. un día, Tutayquire dijo [a los checa]: "no estéis tristes, hijos, digan lo que digan; que sigan despreciándolos; en el futuro, vuestro nombre será checa-huillca y los hombres llamaran con menosprecio a estos que os desprecian: "iquinticitos zancuditos!"

10. unos pocos días después Tutayquire poniéndose de acuerdo con sus otros hermanos, empezó la con- 
Bradymir Bravo / La distribucion y organización del territorio de los huarochiri prehispanicos...

quista de los yuncas de Llacsatambo.

11. cuando estos yuncas supieron del hecho. Muy atemorizados, empezaron a huir a las tierras de colli de abajo.

14. /se dice que/ Tutayquire bajo por las quebradas de Sisicaya y de Mama [convirtiéndose en] lluvia amarilla y roja.

15. entonces los otros hombres lo esperaban en sus propias comunidades a fin de adorarlo.

16. y a estos de ninguna manera los desprecio.

17. al contrario, [les dijo]: "quedaos, pero reconoceréis a mi padre; desde hoy viviréis tratando a los checa de "hermanos" y os consideréis como sus hermanos menores".

(Taylor 1987: 205-209).

En otro pasaje del Manuscrito se relata también lo siguiente de Tutayquire:

\section{"Capitulo 12:}

4. ahora vamos a hablar de las andanzas de Chucpaico, chancharuna, Huariruma, Utcochuco, Tutayquire, Sasinmale y Pachachuyro.

5. /se dice que,/en los tiempos antiguos, como estos que acabamos de nombrar poseían todos numerosos hermanos, solían ir todos juntos a luchar [contra sus enemigos].

7. Tutayquire era el más valiente de todos.

8. por ser tan valiente, fue el quien primero conquisto a los yuncas de estos dos ríos.

9. coloco una vara de oro en lugar que se llama Uncatupi, un cerro negro que se encuentra en la frontera [de las tierras de los] pariacha. [Al realizar este gesto], dijo: "si alguien, como por maldecir a los yuncas, derriba esta [vara], mostrando.

10. el cerro donde la colocó se llama hoy Uncatupi Caparicaya.

11. los otros hermanos salieron de Tupicocha y subieron nuestro antiguo camino-este se llama [el camino] de Tumnacha; [cuando llegaron al lugar] desde donde miramos hacia Lima oyeron que Tutayquire había ya terminado de conquistar todo [ese territorio]; entonces regresaron.

12. ellos también temían mucho a Tutayquire por ser el tan valiente.

13. así, bajaron en la dirección de Huarochirí, hacia Caranco de Abajo.

14. de nuevo, fue el [Tutayquire] quien se adelantó...

15. una de las hermanas de la que llamamos Chuquisuso lo estaba esperando en su chacra con la intención de seducirlo: mostrándole sus vergüenzas y sus senos, dijo: "padre, descansa un poco; antes [de seguir tu camino], bebe esta chichita, este ticticito".

16. Entonces, él se quedó allí.

17. cuando vieron eso, los otros hermanos también se quedaron, habiendo conquistado solo hasta Pachamarca [de] alloca de Abajo.

(Taylor 1987: 217-221).

Tutayquire desciende de los adoradores de Pariaqaqa. Su padre es Pariaqaqa, y como tal es hermano de Chucpaico, Chancharuna, Huariruma, Utcochuco, Sasinmale y Pachachuyro, y todos componen el grupo de los jefes de las comunidades que rinden culto al vencedor de Huallallo Carhuincho. Tutayquire es 
el guerrero valiente, el padre, el fundador de la comunidad y el esplendor de los checa, hermanos menores de los quinti. Es otras palabras un héroe mítico-paqarina o fundador. Tutayquire en esta lista de hermanos no es el mayor, esta posición primogénita caen en la figura de Chucpaico: "C12: 6. Chucpaico, por ser mayor de todos, era tenido en gran estima y paseaba [trasportado] en una litera".

Chucpaico tiene las atribuciones de un kuraka, pues como uno, anda sobre literas (Taylor 1987: 217, Arroyo 2006). Es la cabeza de sus hermanos. El héroe mítico de los quinti. Tutayquire es hermano menor de Chucpaico, por ello los checa son hermanos menores de los quinti. Pero Tutayquire es un guerrero valeroso, y se lanza a la conquista de otras tierras donde pueda ubicar a la comunidad que lidera. Se apropia de las tierras de San Damián, y funda la comunidad de los checa, y de los concha. Desde aquí emprende la conquista de las tierras cálidas de la chaupiyunga Mama ${ }^{12}$ y Sisicaya. Hace huir a los yungas de las sierras, no obstante, y a diferencia de Pariaqaqa, no expulsa a los yungas retrasados sino los recibe como hermanos, con la única condición que estos adoren a su padre Pariaqaqa, este es sin duda una de las estrategias de su éxito y rápida expansión, y característica de su tiempo. Cuando los demás hermanos se dan cuenta de las hazañas y victorias de Tutayquire, ya es tarde. Tutayquire ahora es el héroe victorioso, poseedor de ricas tierras de coca y frutales. Es temido y respetado por sus hermanos, incluso por Chucpaico y los quinti, de los cuales se separa al fundar su propia comunidad en San Damián. Ahora, como gran señor, lidera las campañas de los adoradores de Pariaqaqa hacia las tierras cálidas del sur del territorio de los quinti, pero, como sucedió con su padre Pariaqaqa, una mujer, curiosamente, hermana de Chuquisuso, lo seduce y evita que vaya más allá. Coincidencia que permite sostener su filiación con Pariaqaqa (y parece repetirse en las nuevas generaciones).

Antes de la aparición de Tutayquire, en el seno de un pequeño ayllu afiliado a los quinti, comunidad mayor que concentra los beneficios de dirigir el culto a Pariaqaqa, los checa eran "despreciados" por los quinti, tal vez por ser nuevos en descubrir el culto a Pariaqaqa. Es Tutayquire, quien emprende la empresa para buscar una tierra donde ubicar a su comunidad, donde puedan crecer, sin ser absorbidos por los quinti. Tutayquire no solo lo logra al fundar dicha comunidad en las tierras de San Damián, sino que al hacerlo hace que los checa se hagan más fuertes y numerosos, debido a su tolerancia ante los yungas, incluso más fuertes que los quinti. No obstante Tutayquire está identificado con el culto al camac Pariaqaqa. Para asumir su nuevo rol de conductor del culto a Pariaqaqa, se hace llamar hijo de Pariaqaqa, con lo cual queda a la par de otros jefes: Chucpaico, Chancharuna, Huariruma, Utcochuco, Sasinmale y Pachachuyro, de los cuales será hermano. Si Tutayquire y sus checa, no se enfrentan a los

12. A pesar de lo señalado por Feltham (2005), la no existencia de evidencia de un conflicto serrano costero en el valle medio del Rio Lurín que permita hablar de la expansión de los Huarochirí serranos sobre las tierras del valle medio que se menciona en los documentos históricos. En prospecciones arqueológicas realizadas en el valle medio del Rímac durante los años 2012-2015 en los distritos de Ricardo Palma (sitios de Toboganes, Sitio de Santa Ana Alta), Santa Eulalia de Acapaya (sitio de Mama-Huallaringa), San Bartolomé (sitio de Chucunculla), y San Mateo de Otao (sitio de Puruhuay, y sitio de Chaupimarca también situado en la frontera con el distrito de Santa Cruz de Cocachacra), hemos podido evidenciar la presencia de sitios fortificados pensados con murallas y fosas defensivas dispuestas en la dirección de la rutas de las cabeceras de cerro, ruta del descenso de los serranos de San Damián, Tupicocha y Santiago de Tuna. Esta evidencia arqueológica estaría contradiciendo la propuesta de Feltham de la no expansión serrana y conflicto serrano-costero que se menciona en el mito, y más bien fortalece los pasajes del documento histórico huarochirano. No obstante habría que decir que no se debe descartar la propuesta de Feltham a la ligera, sino considerar la alternativa de que las situaciones y relaciones de los serranos de Huarochirí con los yungas del valle medio de Lurín y con los del Rímac muestran dinámicas diferentes. Los datos y evidencia resultantes de la prospección arqueológica señalada en estos distritos serán presentados en otro trabajo y en otra oportunidad. 
quinti es porque ambos comparten un mismo culto, un mismo camac, un mismo padre, Pariaqaqa. No obstante los checa, otrora "despreciados" pondrán a la par de Pariaqaqa a su proclamado hijo, héroe mitificado que combate en forma de tormenta, lluvia amarilla y roja, fundador de su comunidad, y su nuevo esplendor, Tutayquire. De ahí que los checa, los concha de San Damián, Tupicocha, Tumna, digan: "nuestro padre Tutayquire, nuestro padre Pariaqaqa".

El panorama que nos presenta el Manuscrito, es uno de continua competencia entre las comunidades que se identifican con un mismo culto, es el continuo enfrentamiento entre el prestigio de sus héroes míticos, y su importancia como hijos de Pariaqaqa, la que define su identidad comunitaria. Y sin duda, las hazañas de Tutayquire, sus cualidades y poderes mágicos, le han elevado a la categoría de digno hijo de Pariaqaqa, y con el tiempo, mientras se mitificaba su persona en la memoria de los checa a la categoría de camac, de "héroe mítico- paqarina o fundador". Los checa verán en Tutayquire el modelo y la fuerza para definir su identidad comunitaria, aquella que les diferencie de sus hermanos de culto a Pariaqaqa, de los quinti, aquel que les permita sostener el muy andino principio de competencia, aquel que garantice su libertad y autonomía.

Sin duda el caso de Tutayquire es el mejor exponente del tipo de camac "héroe mítico-paqarina o fundador" de la sierra huarochirana.

\section{LAS HEMBRAS DEL MITO}

\subsection{LOS CAMAC HEMBRA COMO “HÉROE MÍTICO-PAQARINA O FUNDADOR”.}

He señalado anteriormente que la presencia de los personajes míticos como demarcadores contexto-temporales de un momento y orden tiene trascendencia estructural. Como se ha dicho esta puede inscribirse desde una dimensión regional (quizás tal vez e incluso pan-andina) hasta una local, digamos a nivel de grupos comunitarios. Se ha dicho además que esta es también una de las características del tipo de camac "héroe mítico- paqarina o fundador". En el mito de Huarochirí el valor de la hembra parece ser complementariamente asimétrico en relación con la del macho ${ }^{13}$, no obstante como en toda complementariedad que sea andina son el equilibrio medular del momento y orden del tiempo del macho. Volveremos sobre este asunto con más detalle cuando se toque el valor de la hembra del mito en los lazos de justificación de la posesión sobre los antiguos momentos y órdenes.

En el mito de Huarochirí no obstante, se da el caso que ciertos personajes hembras tiene trascendencia local sin la complementariedad de su contraparte macho. Estos personajes míticos están definiendo la adscripción de identidad comunitaria, que los convierte en camac tutelar, pero más que ello en "héroe mítico-paqarina o fundador". Veamos el caso emblemático de los Huichocamari de santo Domingo de los Olleros y su camac hembra Wichuka (Vichuka).

El Manuscrito nos dice "C11: 19. Los allaucamari y los huichocamari también tenían la costumbre de considerar a los checa como hermanos". A raíz del momento y orden de Tutayquire muchos pueblos respetaron a los checa. La ascensión de estos como grupo comunitario emergente, les valió la hermandad de otros pueblos, entre ellos los Huichocamari de los que hablaremos a continuación.

Santo Domingo de los Olleros se incluye en la guaranga de Langasica. Agrupado junto con otros pueblos de varios ayllu como Chatacanche (con sus ayllu Papano y Concha, Suni, Llana (Yana), Colla-

13. Se opta por las denominaciones de hembra y macho a sabiendas que los personajes míticos del Manuscrito tienen naturaleza animal y humana, y no señalan en particular a individuos humanos, sino más bien "energías" que tienden a adoptar formas variadas de acuerdo a las circunstancias del momento y orden (pueden ser huevos, halcones, hombres, lluvia, nuevamente hombres y finalmente una montaña nevada como sucede con los Pariaqaqa; o pueden ser mujeres, luego fuego, luego mujer y finalmente roca de cinco puntas, como sucede con Manañamca o Mamañamca). 
na, Uhcumaria, Llaquaz, Zambilla.), San Pedro de Chuiacancha de Matara (Casica o Cacasica, Quinti, Colcaruna), San José de Chorrillos de Aquipa (Bechuca, Allauca y Acurana), Asunción de Langa (Lina, Yanica, Allumpaia y Allauca) y Santiago de Cohaguayco (Coto). El grupo comunitario de Olleros estaba compuesto por los ayllu Socuia, Alacurco, Uchumari, Limaibilca, Zambilla, Julca Uma Uma, y Llana (Yana) (Rostoworowski 2002: 264). Si bien como lo señala Ramón Joffre, Santo Domingo de los Olleros, aparece como pueblo recién en micciones posteriores al de las reducciones de Briceño, los sitios arqueológicos aledaños de Cerritos y Santa Rosa (Tampu Coto), sugieren la presencia de ocupaciones humanas desde tiempos prehispánicos, además recordemos que el conquistador Alonso de Alvarado en su recorrido a la sierra central desde Lima, se habría topado en 1536 con indígenas leales al inka en “otro paso que se dice Olleros" (Ramón 1999: 20-21).

Arroyo nos dice de Wichuka sería la huaca tutelar del grupo étnico Wichuka o Huichucamari: (Arroyo 2006: 55) "Si el término es correcto por Vichuca, Vichuka o Wichuka como grupo étnico que consideraban hermano a los checas de Warochirí, esto nos induce a presumir que la actual comunidad de Santo Domingo de los Olleros ubicado en la parte alta del valle Chilca y al noroeste de Warochirí, conformaron antes el grupo étnico de los Vichuca o Wichuka..." También recoge la tradición que se tiene de ella: "Vichuca o Wichuka es la montaña sagrada de Santo Domingo de los Olleros, donde reside la doncella Wichukay...principal deidad tutelar de la comunidad..." Gabriel Ramón también ha señalado la proximidad del cerro Wichuka al pueblo de los Olleros (Ramón 1999: 217). "Esta montaña sagrada es identificada como la doncella Wichuka por los "olleranos"... y tienen por memoria un mito de origen, ... nos relató la señora Escolástica León Pérez la siguiente leyenda: Vichuka mantenía relaciones de pareja con el "Cerro Viejo" de la parte baja, con el tiempo, su hermana menor Pachakamq le engañaba por aceptarle los amoríos y tener hijo del Cerro Viejo. Vichuka, al enterarse, se sintió burlada y mancillada por su hermana y su enamorado. Entonces, rompió sus relaciones y por decepción trató de comprometerse con los "Cinco Cerros" (ubicado al noreste del cerro Vichuka)". Quizás hace referencia al Cinco Cerros, sitio arqueológico ubicado en Tupicocha o quizás se refiere a los Pariaqaqa que eran cinco, recordemos que en el llamado Pariaqaqa de Arriba, entorno al lago Mullucocha se encuentra una gran roca labrada donde sobresalen cinco puntas que según se ha dicho representaría a los Pariaqaqa. Esta parte de la narración ¿indicaría que Wichuka buscaba establecer relaciones con Pariaqaqa? Esta parece ser una constante en el mito de Huarochirí, ya que sucedió lo mismo con Chuquisuso quien pidió favores a Pariaqaqa a cambio de ser su mujer, posteriormente lo mismo hizo una hermana suya con Tutayquire (Taylor 1987). Prosigamos con el relato de Escolástica León: "quien [se refiere a Cinco cerros] ${ }^{14}$, al ver que su pueblo necesitaba agua [se refiere al pueblo de Wichuka], trató de congraciarse con su agua y fue cuando le envió un porongo de agua y Vichuka, al rechazar [el ofrecimiento] arrojó el porongo con su waraka (honda) que llegó a dar a Villa de Chorrillos (y hoy se conoce por Pantanos de Villa) y la tapa cayó a Buena Vista de Lurín (y hoy es un abundante manantial). Por esos hechos del destino creen que no hay agua en Santo Domingo y están a expensas de la lluvia del año y, debajo del cerro Vichuka existe un manantial con poca agua que no alcanza ni para los ganados".

Arroyo continua agregando que: "La parte baja de Santo Domingo de los Olleros parece una "cuenca maldita" por donde ha pasado un gran aluvión, como una "maldición de alguien o castigo de los dioses", dejando piedra sobre piedra casi sin tierra. Es tierra cálida o yunga seca con algunos ojos de agua escasa y, sin embargo, es la cuenca que albergó a los mejores alfareros (desde la época precolombina) por la calidad de su arcilla y fueron los famosos olleros del mercado regional, tanto para el truque como para el mercado..." (Arroyo 2006: 55-56) ${ }^{15}$

14. Lo que se encuentra entre corchete ha sido agregado por el autor de este ensayo.

15. Pero, la industria ollera moderna urbana los liquidó y ahora quedan algunos ceramistas para la artesanía suntuaria. No obstante, la gran mayoría de la comunidad hoy se dedica al cultivo de tuna y cochinilla para el mercado nacional y de exportación y, asimismo, hoy es curioso observar la cuenca de piedras sobre piedras en tubos y cruce de tubos de agua (con bombas de agua) por todas partes para irrigar los tunales que van cubriendo a toda la quebrada, con cruce de carreteras trochas para los prósperos tuneros: ¿Milagro del mercado? 
El caso de los olleros y Wichuka resulta particular e intrigante. Se dice que Wichuka es traicionada por su hermana Pachakamq, quien le roba los favores de "Cerro Viejo". Ante esto, su pueblo sufre por el agua, lo cual la obliga a buscar los favores de "Cinco cerros". No obstante de su necesidad Wichuka rechaza los favores de "Cinco Cerros", lo que origina que su pueblo sufra siempre de escases de agua, y por extensión origina el ancestral oficio de los olleros.

Ramón Joffre señala que los pobladores contemporáneos de Santo Domingo tienen una demografía variable ya que gran parte de la población se dedica a la ganadería con lo cual desarrollan un continuo desplazamiento a las estancias a varias horas del pueblo, donde se crían ganado vacuno y caprino. O bien migran estacionalmente a la sección baja de la comunidad en la zona de Manzano a solo 80 msnm, muy próxima al distrito y el sitio arqueológico de Pachacamac. Cuando comienzan las temporadas de lluvia en las alturas algunas familias descienden por las quebradas de Chamaure, Malache y Pucara. (Ramón 1999: 21-22) ${ }^{16}$. De acuerdo con esta perspectiva de traslado vertical, bien podemos sugerir que "Cerro Viejo" que está debajo de Olleros, vendría a ser el sito de lomas de Pueblo Viejo-Pucara. Esto sería posible al tener en cuenta que Manuel Lizárraga ha reportado la presencia de una plataforma artificial, con estructura circular (EA-67) que estaría rodeando a una Huaca tipo afloramiento rocoso en el sitio arqueológico de Pueblo Viejo (Lizárraga 2009), este bien podría tratarse del camac Cerro Viejo de la narración recuperada por Sabino Arroyo entre la gente de los Olleros.

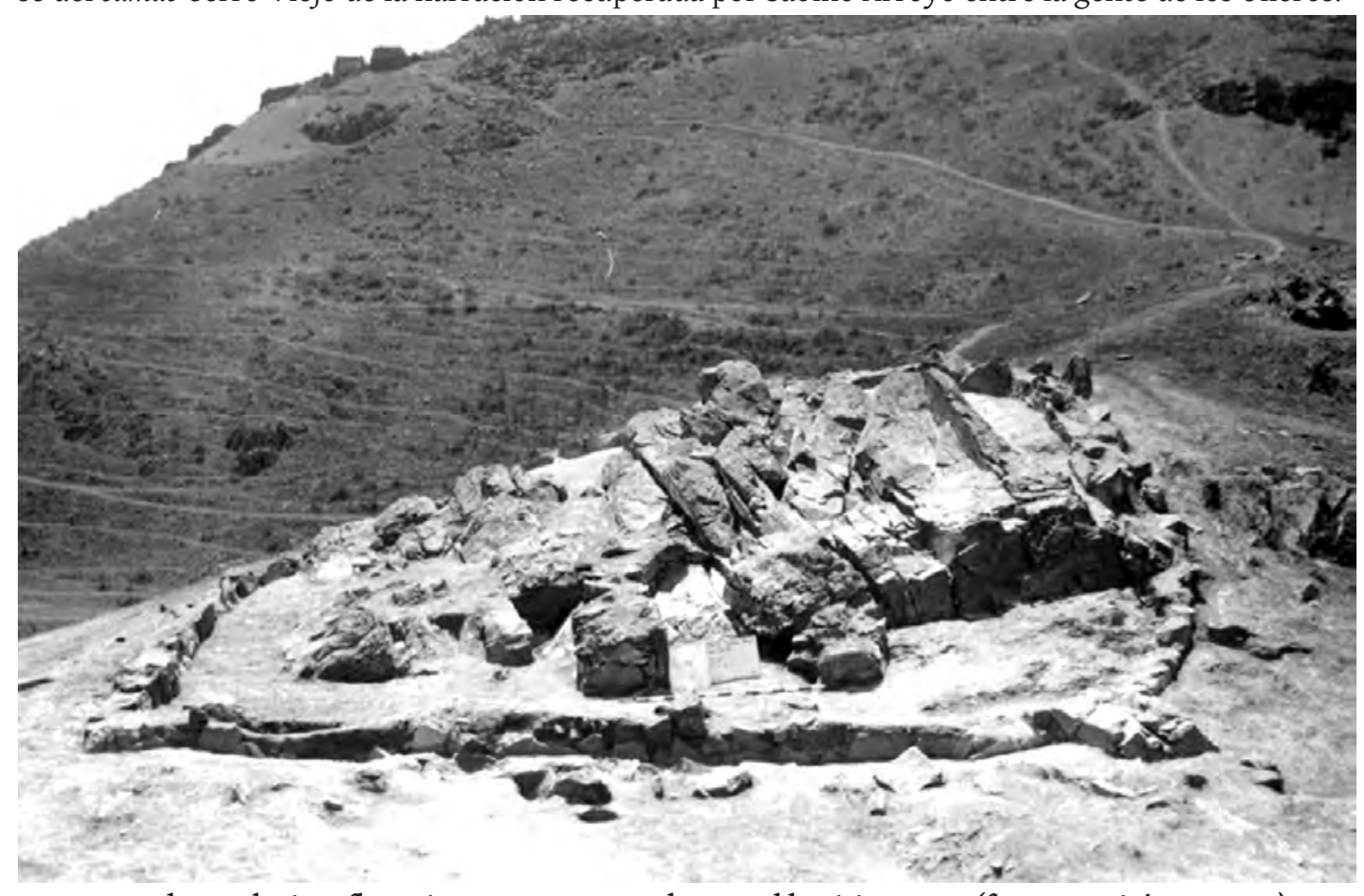

Foto 1: huaca de tipo afloramiento rocoso reportado en Pueblo Viejo-Pucara (fuente M. Lizárraga 2009).

Olleros y Pueblo Viejo habrían mantenido relaciones, lo más probable, de complementariedad económica, es muy probable también que el origen del asentamiento de Pueblo Viejo sea gente serrana dedicada al pastoreo que se está asentando temporalmente en las lomas para aprovechar los pastizales y otros recursos. De este modo en algún momento los de Pueblo Viejo estarían intercambiando

16. Ramón Joffre (1999) ha visto una dinámica de "control vertical de pisos ecológicos" en este fenómeno. 
los alimentos que no estaría producido Olleros (por hallarse en espacio intermedio entre la sierra y el valle bajo, Pueblo Viejo) con los yungas del litoral.

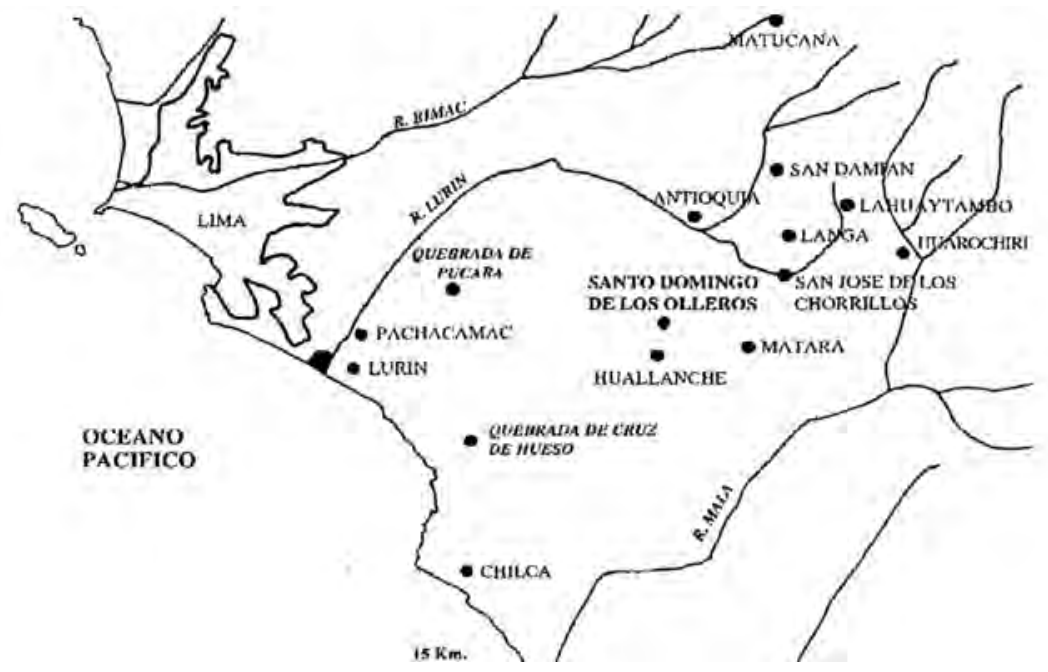

Figura1. (fuente Gabriel Ramón Joffre 1999)

Posiblemente lo que intercambiaban por alimentos sería tiestos cerámicos. Ahora bien, Pueblo Viejo rompe sus lazos de intercambio con Olleros. Ahora establece vínculos con Pachacamac. Para que estos vínculos se fortalezcan es necesario, o la conversión del camac de los Ychsma en hembra o entregar a un pariente femenino suyo, lo segundo sería más factible. El hecho es que estos nuevos vínculos orientan la red de intercambio de Pueblo Viejo hacia el litoral. Esto supone: 1) que el origen de los habitantes de Pueblo Viejo sea serrano; 2) que estos mantenían relaciones de intercambio con los pueblos serranos por estar vinculados originariamente con los Olleros; 3 ) los habitantes de Pueblo Viejo parecen estar habitando las lomas el tiempo suficiente como para redefinir sus prioridades de intercambio, es probable que al asentarse en las lomas de forma permanente finalmente, y teniendo no solo mayor contacto sino que fácil acceso a los recursos costeros, su sentido de pertenencia haya cambiado; 4) finalmente esto habría desencadenado una reorientación de sus vínculos de intercambio a favor de los yungas de Pachacamac, 5) lo que generó que lo Olleros incidieran en una forma económica no muy explotada debido a su circunscripción geográfica casi desértica, fue la agraria, de ahí que el nuevo momento y orden de los olleros necesite con gran urgencia del agua. Salvando los esfuerzos por desarrollar una producción agrícola, la actividad pastoril, también habría sido la actividad comunitaria que soporta el bienestar de los Olleros.

No obstante de esta necesidad, Wichuka rechaza los vínculos con "Cinco Cerros" o Pariaqaqa. La asociación entre "Cinco Cerros" y Pariaqaqa, es factible si se piensa en la naturaleza quíntuple del gran Apu de los Huarochirí y Yauyus (es cinco halcones, nace de cinco huevos, tiene cinco hermanos, sus ritos están asociados al tiempo de cinco días). Recordemos que la oferta de Pariaqaqa o "Cinco Cerros" es la de ofrecer agua en cántaros, esto quizás sugiere que también para Pariaqaqa le era imposible construir sistemas de canales en un espacio casi desértico, y probablemente la única forma de abastecer de agua suficiente a los Olleros haya sido mediante el traslado de grandes cantidades de cántaros conteniendo agua. Esta solución no habría satisfecho a Wichuka. Por lo cual rechazó el ofrecimiento, sentenciado a su comunidad a carecer de un abastecimiento significativo de agua. Sin duda esto habría definido la adscripción de identidad de los olleros hacia el cerro del camac Wichuka, ya que en cuyo pie se hallaba un manantial, única fuente de agua del territorio, tan valiosa para su subsistencia. 
Las difíciles condiciones de la geografía de los olleros, la escasez de agua, habría definido la identidad de estos pueblos, basada en la manufactura de alfares, que intercambiaban por alimentos, de ahí que no solo fueran los más grandes ceramistas de su tiempo de esta parte de la sierra limeña, sino les valió el nombre con el cual se les conoce. Entonces se hace evidente la importancia de Wichuka, no solo debido a que su desventura y su proceder los haya obligado a convertirse en pueblos de artesanos, sino además porque de Wichuka brotaba la única fuente de agua, de la cual simbólicamente habrían dependido para la manufactura de sus alfares y habrían empleado en el consumo de la vida diaria.

Por otro lado el dato histórico nos revela una inclinación de género de las mujeres de Santo Domingo de los Olleros a identificarse con la manufactura alfarera. En el Segundo Libro de Nacimientos de 1891-1915, se registran a los alfareros de la siguiente manera: 3 hombres y 7 mujeres. Lo cual señala que la actividad alfarera era predominantemente femenina, aunque no exclusiva (Ramón 1999: 223). Además, es interesante que esta no sea la actividad predominante, más bien lo eran la agricultura, ganadería y criadero de animales. Volveré a este asunto más adelante.

Ramón Joffre nos cuenta la situación actual de la comunidad de olleros: el pueblo se divide claramente en dos sectores: 1) un sector de casas abandonadas y derruidas, llamada comunidad Yanac, 2) y un sector de ocupación vigente, llamado comunidad Cucuya (Ramón Joffre 1999: 219). Esta división sería resultado del abandono del pueblo de los Olleros que se habría dado a raíz de una drástica sequía en 1924, donde los miembros de la parcialidad emigraron a la estancia de Huallanche (1800 msnm) camino a Chilca, las parcialidades restantes, de Collana y Yanavia se funcionaron en Cucuya (Ramón 1999:221). En la comunidad de Cucuya la tradición alfarera contemporánea es exclusivamente femenina y se halla muy restringida, se transmite entre las mujeres de la familia. Aquí, la participación masculina es más bien auxiliar, ya sea en la extracción de la arcilla o en la venta de las ollas, o asistiendo en algún momento del proceso de producción del alfar (Ramón Joffre 1999: 224).

La relación entre la producción alfarera en los Olleros como una actividad exclusivamente femenina tiene su fundamento en la interpretación del mito de Wichuka. En primer lugar Wichuka es un camac hembra, y es a raíz de su accionar que la producción alfarera se inserta como una expresión de la identidad de la comunidad de lo olleros. Por otro lado, como hemos dicho, la producción alfarera no sería la única actividad sostenible por los Olleros. Ya que se ubicaba en un espacio condicionado por los fenómenos climáticos, donde, después de las ligeras precipitaciones de fin de año, las fuertes lluvias de enero y marzo, provocan la migración estacional de los ganaderos a la zona de Pachacamac lo que genera la suspensión momentánea de la producción alfarera (Ramón 1999: 218). Es posible asumir dos actividades predominantes en la economía de los Olleros, la alfarería y la pastoril. Ahora bien según el Segundo libro de Nacimientos, la alfarería no es la actividad predominante, no obstante es de gran relevancia que esta sea desarrollada mayoritariamente por la población femenina. Al respecto, consideremos el hecho que actualmente todos los alfareros de olleros son mujeres, pero sobre todo que según lo que recoge Ramón Joffre, en la actual comunidad de Cucuya, la trasmisión del conocimiento de la producción alfarera se trasmite entre las mujeres de la familia. Con este conocimiento podemos decir que el hecho de que entre 1891-1915 haya 3 alfareros varones en una población de alfareros mayoritariamente femenina, se debe a que fueron mujeres alfareras, probablemente sus madres o algún pariente muy cercano, las que les transmitieron el oficio de la alfarería, al no poder trasmitir ese conocimiento a una hija o un pariente femenino, posiblemente porque no lo tenían. Este procedimiento suena lógico, si lo que se busca es preservar esta tradición, que viene a ser ante todo una expresión de la identidad de la comunidad de los olleros. 


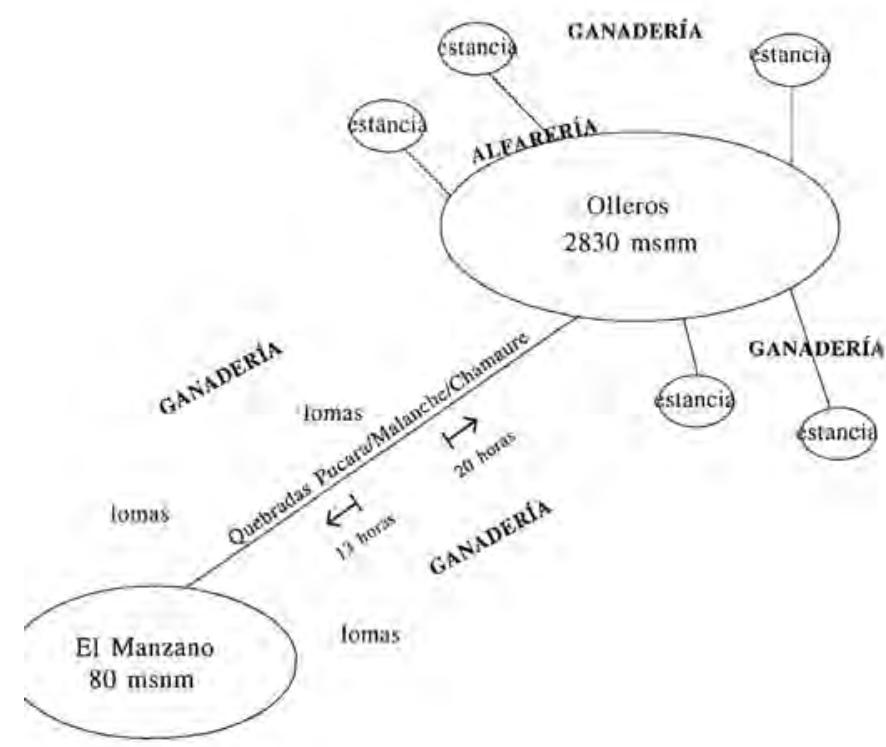

Figura 2. Esquema de uso del espacio de la comunidad Cucuya. (Fuente Ramón Joffre 1999)

El hecho que la actividad alfarera sea un oficio femenino, está estrechamente relacionado con la naturaleza de Wichuka. Que esta sea el camac protector de esta comunidad también se sostiene en el importante papel que juegan las mujeres en el bienestar de la población comunal. Consideremos además que la actividad pastoral y las largas marchas en búsqueda de pastizales debió ser en un principio una tarea masculina, con lo cual el pueblo de los Olleros quedaba en su gran mayoría identificada con la entidad femenina de sus mujeres y de su camac. En un sentido de adscripción a una identidad común, es probable que los pastores rememoren al pueblo de los Olleros y su camac Wichuka como su lugar de origen.

Es por ello que el camac Wichuka, muestra ser vehículo de identidad ancestral, sería la madre de los olleros, vehículo de pertenencia a un lugar, estas comunidades se identifican no solo como pertenecientes a su medio geográfico drástico, sino también muestran ser vehículo contexto-temporal de un momento y orden, ya que con su proceder deja sentenciado a los suyos a la escasez de agua, pero redefine un orden propio, su conversión en un pueblo de mujeres artesanas del barro y pastores trashumantes. Este es sin duda un particular y un buen ejemplo de un camac hembra "héroe míticopaqarina o fundador".

Este tipo de casos, bien sugieren lo equivocada que está la interpretación etnohistórica en torno a seguir creyendo que en su unanimidad las provincias de Huarochirí y Yauyos era el espacio étnico Yauyu. Si bien es cierto, los Huichucamari llaman hermanos a los checa, esto ha de deberse a la red de intercambio que habrían contenido, y por qué quizás fueron estos los que intentaron abastecer de agua a los Olleros, sino recordemos que un "Cinco Cerros" se halla en Tupicocha. ${ }^{17}$ Se trata por ende de un grupo de ayllus con una identidad común muy bien definida.

Por otro lado, al revisar la composición de ayllu de los pueblos que componen la guaranga de Langasica, notamos que existe una relación estructural interna entre el grupo comunitario de los Olleros y el de Catacanche. Se sabe que los ayllu Papano y Concha de Chatacanche se reducen en San

17. Al respecto la cresta de cinco picos llamada Cinco Cerros en el distrito de San Andrés de Tupicocha muestra evidencia arqueológica de una ocupación anterior al tiempo del Tawantinsuyu. 
Damián (Rostoworowski 2002: 264), lo cual relaciona a este con los checa, además está claro que el ayllu Concha seria ayllu Checa. Ambos grupos comunitarios presentan los ayllu de Uchumari, y Zambilla, y Llana o Yana, probablemente este último introducido en tiempos de los inka. Este grupo de ayllus compartidos permiten sostener algún tipo de relación. Probablemente los Chatacanche serían parcialidad de los olleros, y ambos comprenderían a los Huichucamari. La recurrencia, sobre todo del ayllu Uchumari, revela una relación directa con Huichukamari. Las terminaciones en - mari, podrían estar indicando a un mismo grupo. Recordemos que tanto Suni, y Llaquaz son ayllu de pastores, lo cual concuerda con la posición de Cantacanche en la geografía serrana (posición alta) por lo cual esta sería una parcialidad que dentro de sus funciones se dedica al pastoreo. De ser Catacanche y Olleros parte de la adscripción de identidad al camac Wichuka, se entendería que los Huichukamari son hermanos de los checa a través de Catacanche.

\subsection{LAS HEMBRAS DEL MITO Y LOS LAZOS QUE JUSTIFICAN LA POSESIÓN SOBRE EL ANTIGUO MOMENTO Y ORDEN.}

El caso del camac Wichuka es particular, no es el típico caso del personaje mítico hembra del cual se narra en el Manuscrito. Por lo general estos personajes míticos hembra, aunque trascendentales y singularizados por sus formas de culto, y las fiestas que se les hacen, resultan ser complementarias. Su momento y orden está directamente relacionado al momento y orden del camac macho. Sucede con Manañamca (Mamañamca) complemento del momento y orden de Huallallo Carhuincho; el caso de Chaupiñamca es más complejo, primero como complemento del momento y orden de Huatyacuri, luego como complemento del momento y orden de Pariaqaqa, y finalmente complementa a Rucanacoto. La naturaleza complementaria de los camac hembra tiene una razón justificadora. Es por medio de ellas que el camac macho justifica su poder y posesión sobre las tierras del antiguo momento y orden del tiempo de los camac desterrados, derrotados o vencidos, y depuestos. El caso de Chuquisuso y su hermana, el de Miriahuato, es algo más sencillo y son los complementos estructuralmente más pequeños que justifican la apertura del tiempo de los camac macho entre los grupos locales.

Veamos con el caso más complejo de Chaupiñamca nuestra perspectiva de camac hembra como complemento del momento y orden de los camac macho, y como medio justificante de poder y posesión sobre los antiguos tiempos de los camac vencidos y otras particularidades.

\section{CHAUPIÑAMCA: DE HUATYACURI, PARIAQAQA A RUCANACOTO.}

Alejandro Ortiz, sugiere que: "El relato sobre Huatyacuri trata de dos sujetos complementarios y relacionados entre sí: de un cosmos y de una familia. Lo que ocurre en uno ocurre en el otro. Un mundo debe de acabar porque una familia está enferma y debe también de acabar. Cada uno y respectivamente son la causa y la consecuencia del otro. Una vieja familia y un viejo mundo terminan; un mundo y una familia nuevos empiezan. Esta solidaridad dentro los dos temas responde y es expresión de una concepción andina aun persistente: la familia y el cosmos están vinculados entre sí. El orden y el desorden del uno se ven reflejado en el otro... En la historia de Huatyacuri se trata de unos seres poderosos, casi divinos, que cometen un desarreglo aniquilador en el seno de su familia, y por eso al mismo tiempo esa familia poderosa está enferma, acaba porque un nuevo mundo, el de Pariacaca, está naciendo. Una nueva familia, la de Huatyacuri y su mujer, surge a la par de la renovación cósmica."(A. Ortiz 1993: 128-129).

El nuevo orden y familia emergente, el de Huatyacuri, el de Pariaqaqa, no obstante no se encuentra desvinculado del antiguo orden y la familia que decae, como lo refiere Ortiz, Tiene la necesidad de justificar su poder en los genes de la familia que agoniza, la hija de Tamtañamca. El orden y la familia antigua no muere, no desaparece, simplemente se reduce en la persona de Chaupiñamca, en ella se re- 
sume su naturaleza y su memoria e intenta prevalecer adaptándose al nuevo orden y la nueva familia de la cual es parte una descendiente suya, y por lo cual los descendientes de esta misma nueva familia serán también parte de la suya. El relato de Huatyacuri, entonces, no es el relato del nacimiento de una nueva "fuerza o energía animadora de los hombres" que surge exterminando la antigua energía animadora del antiguo orden y la familia antigua. Como en todo ciclo andino, en el Huarochirí prehispánico los camac no mueren, son derrotados como fue derrotado Yanañamca Tutañamca, como fuera derrotado Huallallo Carhuincho, son expulsados, entonces vagan por otras tierras buscando siempre a los hombres que necesiten ser animados, como Huallallo entre los Casta, luego en los Collas, o los Antis, hasta que la memoria que guardan sus descendientes desaparezca. Estos camac no mueren, simplemente se olvidan.

Según A. Ortiz, la acción del relato sigue el principio cosmogónico andino de que para que un nuevo orden se establezca, el establecido debe ser destruido. Según el autor esta opera en el relato en dos procedimientos (A. Ortiz 1993:129):

- Por la emergencia u acción de una nueva divinidad, Pariaqaqa, o la de un nuevo miembro familiar, Huatyacuri, que entra en el círculo de su mujer (parte del orden y la familia que decae). El, y gracias a la alianza de pareja, va a sanar a una divinidad enferma.

- Por una competición. Huatyacuri gana en una serie de desafíos a su cuñado.

La afirmación de Ortiz es correcta en ese sentido, mas como lo hemos mencionado anteriormente, no lo sería su afirmación de que el antiguo momento y orden es destruido por el nuevo. Este, el nuevo, necesita justificar su tiempo por medio de lazos ancestrales que lo vinculen al antiguo tiempo de los camac depuestos.

R. Shady, en su análisis del papel de la coya Mama Ocllo del linaje Hurin de Viracocha Inka, usado por Pachacutic como vehículo para legitimar el nuevo momento y orden inaugurado por el, el tiempo de los Hanan Cuzco, nos señala sugerentes ideas que explican esta discusión. Vemos brevemente estas implicancias (Shady 1998):

1. Los Hurin Cusco tenían el control político en el Cuzco antes de que Pachacutic instaurara el dominio de los Hanan Cuzco. La distinción entre Hurin y Hanan no es nueva en los Andes, estaba arraigada en la tradición (...), vinculada con los movimientos de poblaciones y la institución de los recién llegados a territorios previamente ocupados. Hanan versus Hurin tendría su correlato en la oposición de Llacuaz y Huari en la sierra de Lima.

2. La nobleza de Hurin Cuzco mantuvo su poder y privilegios de clase como señores tradicionales. Pachacutic busco legitimar el nuevo orden social, impuesto a través de acciones de conquista, por una alianza matrimonial que reforzara la nobleza de su linaje (...) concertó el matrimonio de su hijo Túpac inca Yupanqui con la noble de Hurin, Mama Ocllo. Posteriormente, Pachacutic eligió como sucesor al hijo de esta pareja (que sería Wayna Capac), a pesar de su corta edad, pues él representaba al primer inca con derecho natural al gobierno después de viracocha (...)

3. (...)Si se considerasen algunos indicios sobre la normas de sucesión en las sociedades andinas, ella en su condición de mujer habría concertado la riqueza de su linajes y se hallaba respaldada por el poder que este tenía como casa noble antigua, de gran prestancia y opulencia (...) El matrimonio con esta coya habría significado para Túpac Yupanqui no solo un refuerzo en el derecho de sucesión al gobierno por tratarse de un mujer principal, y el acceso a los cuantiosos bienes de su linaje, sino el incremento de poder por la ligación de los Yupanqui de Hanan con un linaje tradicional de Hurin y el apoyo de los nobles de este destacado linaje (...) 
Bradymir Bravo / La distribucion y organización del territorio de los huarochiri prehispanicos...

4. La casa religiosa de Viracocha, tradicional y de gran prestigio en la zona del Cusco, antes de Pachacutic, poseía poder político y económico fuertes, y estaba ligado a la nobleza de Hurin (...) este grupo fue (...) relegada frente a la nueva casa religiosa del sol, (...) no óbstante (...) mantuvo sus bienes y privilegios (...)

5. (...) Las casas nobles de Hurin, ente ellas la de Viracocha, mantuvieron sus privilegios de clase en el nuevo orden introducido por Pachacutic, porque representaban a la clase dominante de la sociedad a la que debió estar enlazado el grupo al que pertenecía el nuevo inka, respetando sus privilegios.

En el mito, Pariaqaqa viene a ser la contraparte de Pachacutic, quien necesita legitimar su poder a través del matrimonio de su hijo Huatyacuri con Chaupiñamca representante del antiguo orden de Anchicocha y la cual es del linaje de Tamtañamca. Pese a estar eclipsado, el nuevo momento y orden necesita vincular su descendencia con el antiguo momento y orden. Huatyacuri es un advenedizo, extranjero y pobre, y pese a ser hijo de un camac verdadero. De ahí su insistencia en trocar la salud de Tamtañamca por la mano de su hija. Pese a sus evidentes dones y sus hazañas de curandero es retado por su cuñado. El matrimonio es la vía de vínculo entre un nuevo momento y orden y otro antiguo. El cuñado de Huatyacuri también está unido por este vínculo a Tamtañamca, de modo que reclama sus derechos, que son también los derechos del antiguo momento y orden que se resiste a desaparecer y que se representa en él. Huatyacuri tiene que vencerlo antes de heredar el poder de Tamtañamca. El procedimiento de competición que nos menciona Ortiz viene a ser el último intento del antiguo momento y orden por prevalecer. Es además la competencia entre dos personajes con derechos a heredar pues se hallan vinculados por el matrimonio con el antiguo linaje de Tamtañamca. Finalmente vence el pobre, el extranjero, el advenedizo, y con él la nueva familia que justifica su posesión sobre las tierras del tiempo que se desaparece.

Este principio de heredad, parece ser muy antiguo. Podemos decir que el tiempo de Yanañamca Tutañamca, es el tiempo de los ñamca, que parece ser la naturaleza originaria y local de los camac de Huarochirí. Huallallo Carhuincho llega a Huarochirí, vence a este camac. No obstante no parece exterminar el tiempo de los ñamca, la memoria del momento y orden del tiempo de Yanañamca Tutañamca, subsiste en una serie de alianzas matrimoniales en que se ve envuelto Huallallo para justificar su poder sobre la heredad del antiguo tiempo. Ya hemos visto como Huallallo tenía muchas mujeres y buscaba insistentemente a otras nuevas para afianzar su poder, precisamente por pretender a una es que Wampu finalmente logra derrotarlo.

Huallallo no ha matado un tiempo anterior al suyo, este sobrevive en sus mujeres. Manañamca o Mamañamca, es un camac ñamca, probablemente del linaje de Yanañamca Tutañamca. Esta, como sus otras mujeres, legitima su posesión sobre las tierras del antiguo momento y orden al cual pertenecen sus mujeres.

Ahora bien, surge Pariaqaqa y vence a Huallallo y su linaje familiar. Pero no así ha destruido los vínculos con el tiempo de los ñamca locales y originarios. El tiempo de Yanañamca Tutañamca prevalece en el tiempo de Pariaqaqa, en una descendiente de su linaje, Chaupiñamca. Para el mito huarochirano prehispánico, Chaupiñamca viene a ser el ADN mitocondrial del culto local, primigenio y originario a los camac ñamca. Es por ello que esta no es un camac de la categoría "héroe mítico-paqarina o fundador", como lo es Wichuka, también camac hembra. Como el ADN mitocondrial, la heredad de posesión sobre la tierra y poder sobre los tiempos se hereda por vía materna, solo se transmite de madres a hijas.

Ahora bien, habrá que decir, que no obstante y a diferencia de los Hurin, los de Anchicocha no conservan sus privilegios, los extranjeros lo usurpan y destierran a los locales con una tormenta de lluvia que los arrastra hasta las tierras del mar, el cual sería su lugar de procedencia. Es decir tampoco 
estos tienen la heredad de esas tierras. Recordemos que Tamtañamca, falso camac, enferma a causa del adulterio de su mujer que está carcomiendo sus dones como gran huillca (Taylor 1987). Ahora bien, Tamtañamca es del linaje de los ñamca, primigenio de esas tierras. Pero este no tiene la heredad de su tiempo. Sería su mujer, la que posee la heredad, ya que como hemos dicho esta se transmite por vía materna, de madre a hija. Su mujer, es adultera, es decir Tamtañamca ha perdido el derecho a la heredad de los ñamca que le garantizaba su matrimonio. Enferma, sin poder sobre su tiempo no puede curarse. Cae por ende un periodo de transitoria renovación donde surge Huatyacuri y alcanza la heredad de los ñamca. Al perder la heredad el linaje de Tamtañamca y los suyos, no tienen como justificar su presencia sobre las tierras de los ñamca, por lo cual son expulsados a su lugar primigenio. En otras circunstancias, como bien lo señala el caso de los Hurin con su representante Mama Ocllo, el linaje de Tamtañamca y los suyos habrían conservado sus privilegios, como sucedió con el linaje de Yanañamca Tutañamca en tiempos de Huallallo. Así como el matrimonio permite tentar la heredad de las tierras y los tiempos, en el mito de Huarochirí, el adulterio quita todo derecho a esta heredad.

Al reparar en el caso de Wampu y su lucha con Huallallo (que ya narramos anteriormente), vuelve a relucir la trascendencia de los vínculos matrimoniales y el del personaje mítico hembra. Ambos se encuentran en una competencia por hacerse de aliados entablando matrimonio con las huacas locales.

Cuando se evalúa el Manuscrito Quechua de Huarochirí, no se puede precisar cuándo Huatyacuri cede a su mujer a Pariaqaqa. Cabe la posibilidad que Huatyacuri se haya convertido en Pariaqaqa. Recordemos que este presencia el nacimiento de su padre, caso inusual (Taylor 1987). Esto quizás este sugiriendo que Huatyacuri llega a convertirse en Pariaqaqa, que ambos compartan la misma mujer lo sugiere. Además, recordemos que Chaupiñamca permite poseer los derechos de la heredad de los ñamca, por lo cual si Huatyacuri se convierte en Pariaqaqa, es lógico que esté conservado a su mujer lo cual lo identifica. En lo particular se debe considerar otras interpretaciones diferentes: 1) Pariaqaqa, como camac advenedizo, necesita de la heredad de los camac para legitimar su poder, por lo cual se apropia de Chaupiñamca, y del derecho de su heredad, Huatyacuri solo ha sido un vehículo para lograrlo ${ }^{18}$. 2) en algún momento desaparece de la escena Huatyacuri, como se narrará más adelante Chaupiñamca parece recuperar su libertad y se entrega a los placeres sexuales ${ }^{19}$, finalmente será $R u$ -

18. Además cabe la posibilidad que este sea el quinto hermano. Sino recordemos que el Manuscrito menciona a: Pariacaca, Churapa, Puncho, Pariacarco (Taylor 1987, Arroyo 2006). Arguedas señala un posible quinto hermano Sullcayllapa ("quinto hermano menor") (Arguedas 1966). Si interpretamos el mito de nacimiento, Pariaqaqa nace de cinco huevos, del cual salen sus hermanos, por lo cual los cinco serian todos Pariaqaqa, y no necesariamente uno de ellos. Así automáticamente Pariacaca queda excluido de la lista de hermanos que lo componen.

19. Se dice también de ella que (Taylor 1987: 203):

"Capitulo 10:

47. y bailaban otro llamado Casayaco.

48. /se dice que, / cuando bailaban el Casayaco, Chaupiñamca se regocijaba mucho.

49. porque este lo bailaban desnudos.

50. colocándose solo una parte de sus ornamentos y cubriendo sus vergüenzas con taparrabos [compuestos de] solo un paño de algodón, solían bailar. regocijaba mucho.

52. /según cuentan,/ la época en que lo bailaban era de gran fertilidad." 
Bradymir Bravo / La distribucion y organización del territorio de los huarochiri prehispanicos...

canacoto quien la satisfaga definitivamente. Es posible que ante la desaparición de su hijo, Pariaqaqa adopte a Chaupiñamca como hija, hermana, y mujer. Naturalmente su razón está en mantener en su poder la heredad de los ñamca.

Dejando de lado la discusión de si Pariaqaqa es Huatyacuri o no. Volvamos a nuestro asunto entorno a la trascendencia del personaje mítico hembra.

Pariaqaqa, ahora marido, hermano, y padre de Chaupiñamca, ordena (Taylor 1987: 197-195):

"Capitulo 10:

8. la primera [de estas] mujeres, Chaupiñamca, siguiendo las instrucciones de Pariacaca, se fue a morar a Mama de abajo.

9. la mujer llamada Manañamca $a^{20}$ andaba diciendo que era ella quien animaba a los hombres.

10. algunos hombres dicen que, /según la tradición, / Chaupiñamca era hermana de Pariaqaqa.

11. Ella misma afirmaba que Pariacaca era su hermano."

Otro dato no dice las razones de este cambio de morada (Taylor 1987: 197):

"Capitulo 10:

19. /cuentan que / en los tiempos antiguos, esa mujer andaba con forma de ser humano y solía pecar con todas las huacas.

20. entonces no encontraba ningún varón a su gusto.

21. había un varón, una huaca llamado Rucanacoto [cuyo santuario se encontraba] en el cerro que domina Mama;

22. los hombres, que tenían un pene pequeño, le pedían a Rucanacoto que se lo agrandara.

23. y el, por tener un pene grande, consiguió una vez satisfacer enteramente a Chaupiñamca.

24. Por eso, juzgando que el solo era varón auténtico y que solo con él, de todos los huacas, iba a quedarse para siempre, se transformó en piedra y estableció su morada en Mama."

El cambio de morada de Chaupiñamca obedece a las siguientes razones: 1) ocupar Mama de Abajo, donde antes estaba la morada de Manañamca. 2) sustituir el culto de la mujer de Huallallo, Manañamca.

Recordemos, que estos sucesos son anteriores a las hazañas de Tutayquire, por lo cual Mama no pertenece al culto a Pariaqaqa. Desterrado Huallallo y Manañamca, surge otro camac en Mama, el viril Rucanacoto. El recuerdo de Manañamca debía estar fresco entre los habitantes de Mama de Abajo. Pariaqaqa necesitaba introducir su culto en los de Mama. Entonces envía a Chaupiñamca, a sustituir a Manañamca. No obstante para lograr su cometido, esta no es más su mujer, ahora es su hermana, y el camac hembra anda difundiendo su nueva posición en la familia de Pariaqaqa. Seduce a Rucanacoto, y logra asentarse en Mama de Abajo. El vínculo sexual entre Rucanacoto y Chaupiñamca debe interpretarse con algún tipo de lazo matrimonial, esto sin duda garantizó la alianza de Mama al culto de

20. La confusión entre Chaupiñamca y Manañamca o Mamañamca es sugerente, quizá estas sean la misma. 
Pariaqaqa, ya que como se rumorea esta es su hermana y por tanto Rucanacoto llega a ser su cuñado. Parece repetirse las circunstancias que llevaron a Huatyacuri a vencer a su cuñado. No obstante el Manuscrito no señala un enfrentamiento entre Pariaqaqa y Rucanacoto. ${ }^{21}$

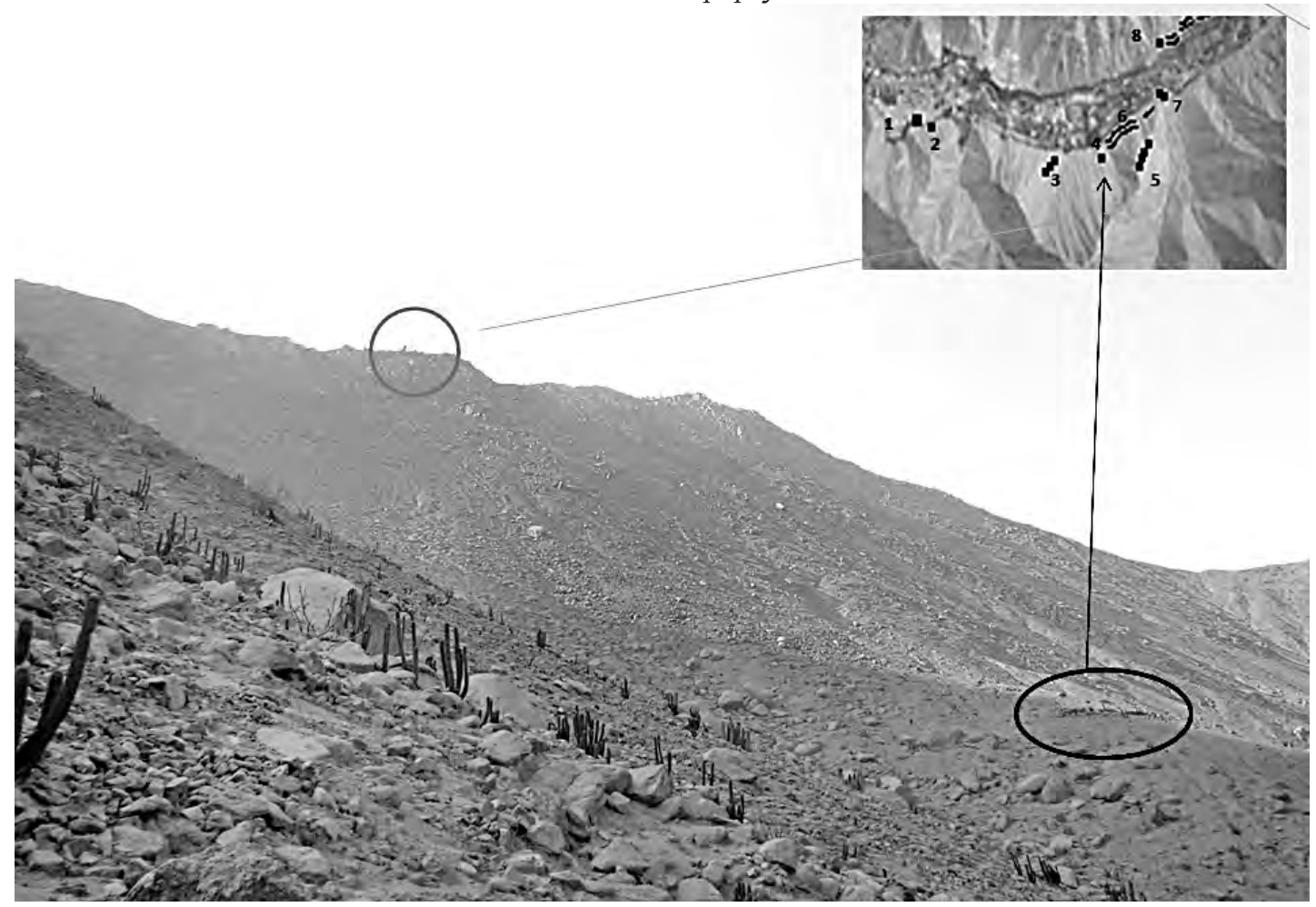

En la foto la ubicación de la huaca Rucanacoto (una enorme peña en la cresta del cerro que se halla a la margen izquierda de la quebrada de Santa Ana, margen izquierda del río Rímac, distrito de Ricardo Palma en Huarochirí) y un posible espacio ceremonial (4) asociado directamente a él. El santuario de Mama se encuentra al otro lado de este cerro (1 y 2 en la foto). Según el manuscrito Chaupiñamca que ocupa el santuario de Mama y Rucanacoto se encuentran en el cerro que domina Mama. Ambos adoratorios comparten el mismo cerro aunque se encuentran divididos por una pequeña quebrada que parte el cerro mayor.

21. Según el manuscrito quechua de Huarochirí (Taylor 1987: 197):

"Capitulo 10:

21. había un varón, una huaca llamado Rucanacoto [cuyo santuario se encontraba] en el cerro que domina Mama;

22. los hombres, que tenían un pene pequeño, le pedían a Rucanacoto que se lo agrandara.

23. y el, por tener un pene grande, consiguió una vez satisfacer enteramente a Chaupiñamca.

24. por eso, juzgando que el solo era varón auténtico y que solo con él, de todos los huacas, iba a quedarse para siempre, se transformó en piedra y estableció su morada en Mama."

Rucanacoto se encontraría en el área del antiguo santuario de Mama en la reducción de San Pedro de Mama, actual Ricardo Palma. Exploraciones arqueológicas realizadas en el valle medio alto del Rímac nos ha permitido identificar la posible localización de la huaca Rucanacoto. Los mismo que este camac, nuestras prospecciones nos han permitido identificar la posible ubicación y existencia de otro camac en el distrito de Santa Cruz de Cocachacra, se trata de una gran peña en forma de busto animal asociado a un espacio amplio y cercado de tipo ceremonial, junto al precipicio de una quebrada subsidiaria de la quebrada de Sisiyaya que se halla en la margen izquierda del rio Rímac. En el vientre de esta gran peña se ha identificado la presencia de pintura rupestre y petroglifos, lo cual la convierten en un candidato potencial a ser identificado como camac, la duda recae esclarecer si se trata bien del camac Chuquihuampo o del camac de los ayllu Suquia el llamado Suquiawillca, ambos tiene presencia marcada en dicho territorio y los documentos permiten relacionarlo a la peña. Seguramente estas discusiones serán aclaradas más adelante en otro trabajo, así como la mención de los datos más detallados de los hallazgos reportados en dichas prospecciones. 


\section{UNA INTERPRETACIÓN: IDENTIDADES DE GÉNERO EN LA ADSCRIPCION DE LAS IDENTIDADES DE CULTO}

Almudena Hernando nos dice que no existe el concepto de género como algo cerrado, definido, sino como una diferencia en el porcentaje en que cada persona desarrolla el deseo amoroso y el deseo hostil, y que por tanto hemos tendido a llamar como femeninas aquello donde el deseo amoroso prevalece y masculinas donde el deseo hostil prevalece (A. Hernando 2007: 12).

La ecuación que propone A. Hernando (2007) en torno a las identidades de género nos permite discernir en torno a la naturaleza de las identidades de culto en el mito histórico de Huarochirí. Pero antes de ver este asunto en particular veamos otros previos que guardan estrecha relación con aquello que se discutirá más adelante.

\begin{tabular}{|l|l|l|l|}
\hline SEXO & ESPECIALIZACION & PODER & DIMENCION \\
\hline Mujer $\longrightarrow$ Deseo amoroso $\longrightarrow$ Sobre las emociones $\longrightarrow$ Grupo social \\
\hline Hombre $\longrightarrow$ Deseo hostil $\longrightarrow$ Político $\longrightarrow$ Individual \\
\hline
\end{tabular}

Basado en A. Hernando 2007

\section{Ecuación de las identidades genero de A. Hernando}

El camac hembra es la heredera de la potestad del tiempo (momento y orden) de los camac machos. Cuando revisamos la ruta de los personajes míticos en los documentos históricos, el folclore, en la memoria ancestral de los pueblos de Huarochirí, el contraste de la movilidad y carácter errante entre el camac hembra y el camac macho es notorio. Los camac macho van y vienen, se desplazan a sus anchas sobre el territorio serrano, sin ataduras que los sujeten con un lugar definido hasta que finalmente deciden quedarse en una peña, en un cerro, en puquial, en una cocha, en un nevado, o usurpando algún templo de un camac vencido. Hay quienes incluso descienden hacia las proximidades del mar, como lo hizo Cuniraya.

En este carácter errante sin embargo hay al parecer un discurso coherente que marca las pautas de tales idas y venidas. Los camac macho se desplazan por el territorio serrano persiguiendo los favores de los camac hembra: parecen buscar entre las comunidades el favor sexual de las hermosas doncellas, así como lo hicieran Pariaqaqa buscando los favores de Chuquisuso, así como Huatyacuri buscando los favores de Chaupiñamca, como el desesperado Cuniraya que persigue a Cahuillaca hasta su trágico destino en el mar de Pachacamac, o como el desafortunado Huallallo Carhuincho que buscando los favores de la hermosa doncella, mujer del Wampu de los Huanza y de los Carampoma, terminó perdiendo sus testículos.

El dominio sobre los pueblos en el mito no solo está representado en las mágicas disputas entre los camac, también está simbolizada por el coito sexual entre los personajes míticos. Tomar posesión de la doncella de la comunidad que se pretende dominar, parece ser incluso más importante que destruir al camac o al héroe mítico-paqarina o fundador que anima a esa comunidad.

Al revisar el caso de Huatyacuri, es inevitable hacer referencia al hecho inusual que el hijo asiste al nacimiento del padre, el cual en forma de cinco huevos espera en el cerro Condorcoto por su propio 
nacimiento. Nótese que en el mito la destrucción de la comunidad de los yungas de Anchicocha al ser arrasados por las lluvias de colores de Pariaqaqa, se da después de que Huatyacuri establece vínculos sexuales y matrimoniales con la hija de Tamtañamca el huillca falso de Anchicocha. Al enterarse de que Huatyacuri y Chaupiñamca consuman su unión mediante el coito sexual, el nuevo cuñado de Huatyacuri, hombre rico de la comunidad, enfurece y reta a Huatyacuri con la finalidad de desprestigiarlo ante los suyos. Al desafío del cuñado de Huatyacuri, asisten tanto los contrincantes como sus mujeres, el mito no narra que ambos compiten como pareja ante sus rivales. Curiosamente una vez vencido el marido de la hermana de Chaupiñamca por Huatyacuri recién Pariaqaqa nace y arrasa con los pueblos yunga de Anchicocha, pero no así con la mujer de Huatyacuri (Taylor 1987).

Debemos interpretar esto como: 1) al perder el derecho a la heredad Tamtañamca, debido al adulterio de su mujer, en el panorama queda con Huatyacuri esposo de Chaupiñamca, y su cuñado el hombre rico de la comunidad; 2) ambos tienen el derecho a heredar la potestad del tiempo (momento y orden) que perdió Tamtañamca; 3) el desafío del cuñado de Huatyacuri representa el encuentro que definirá cuál de los dos ha de heredar por medio de sus mujeres el derecho a la potestad del tiempo de Tamtañamca. El hecho que las mujeres participen asistiendo a sus maridos en el desafío representa la necesidad de legar su suerte con la de sus maridos, si estos vencen estas habrán vencido, y heredaran la potestad del momento y orden antiguo, que solo es legada a las mujeres del mito; 4) derrotado el cuñado de Huatyacuri, Chaupiñamca hereda el derecho a potestad del tiempo de Tamtañamca; 5) recién entonces Huatyacuri, por medio de los vínculos sexuales y matrimoniales que comparte con Chaupiñamca, tiene el poder que le justifica arrasar por vías de su padre Pariaqaqa a la comunidad del cuñado vencido.

El Manuscrito Quechua de Huarochirí nos muestra la gran necesidad de los camac de hacerse de las mujeres (Taylor 1987):

"Capítulo 31:

8. Así, equivocándose de camino se fueron en dirección a Yauyos creyendo que quizás sus hermanos habían ido por aquellas partes.

53. /se dice que, / en [la laguna de] Yansa había un huaca de nombre Collquiri.

54. Por servir [llacsamisa] a estos huacas] (¿Yansa y Collquiri?), cada año todos los concha se esforzaban en cultivar maíz para alimentarlos.

55. En aquella época, Collquiri deseaba mucho [tener] una mujer.

56. Asíque fue hasta Yauyos y hasta Chaclla buscándola por todos partes.

57. Pero no la encontró.

153. Cuando [él mismo] estuvo a punto de morir, sus sobrinos, los hijos de Hualla, de vuelta de los Yauyos, se casaron con las hijas de Cunocuyo -el padre de estas se llamaba Yasali".

Al igual que con el caso de los parientes y el propio Collquiri, el manuscrito de Ávila, muestra casos similares. La pregunta inevitable que nos surge aquí es ¿Qué buscan en realidad insistentemente los camac machos cuando buscan a sus mujeres? Estos buscan hacerse por medio de estas del derecho de la potestad del momento y orden de las comunidades animadas por los camac machos rivales. En otros términos, buscan poder.

Norbet Elías nos dice que el poder es una: "expresión de una posibilidad particularmente grande de influir sobre la autodirección de otras personas y de participar en la determinación de su destino" (A. Hernando 
2007: 10). No obstante estos camac machos, personajes viriles, guerreros, y mágicos, lo que parecen buscar es un tipo de poder en específico. Ahora bien, ¿a qué tipo de poder en específico nos referimos?, pues aquí la respuesta parece encontrarse en la ecuación de A. Hernando mencionada líneas atrás.

Dos formas de poder están relacionados con la naturaleza de identidad de género, aunque no de forma exclusiva, ya que muchos de estos poderes son compartidos en menor y mayor grado entre los hombres y las mujeres: estos son el poder público o político, y el poder sobre las emociones (Hernando 2007: 10-11):

1) El poder público o político esta encarnado en la figura del líder, en aquel que ha decidido el destino de los demás. Este poder está vinculado con el hombre, y es el deseo hostil lo que lo mueve. Este deseo hostil no significa violencia, sino más bien un impulso a la individualidad graduada de las personas que integran un grupo social. Un deseo que busca establecer distancia con los demás, que busca hacernos sentir y vernos como distintos, que aspira a diferenciarse de los otros, a individualizar las identidades.

2) El poder sobre las emociones y de las relaciones, aquel que no se ejerce a través de la distancia emocional, sino a través de intensidad de los vínculos emocionales, el que controla al otro a través de la emoción y no de la razón. Este tipo de poder está vinculado con la mujer y el motor que la mueve es el deseo amoroso. A diferencia del deseo individualizante hostil, el deseo amoroso, no busca diferenciarse de los otros, sino aspira a establecer vínculos de comunidad, se orienta en un sentido de colectividad estrechada por las relaciones emocionales en grupo, como tal vincula al grupo social como un colectivo y no como un individuo.

A lo largo de los pasajes expuestos en estos capítulos la personificación de los poderes políticos o públicos y los poderes sobre las emociones se identifican con los personajes míticos, con los camac que venimos caracterizando hasta aquí.

La figura del líder que encarna el poder político o público que nos menciona A. Hernando, bien puede personificarse en el camac héroe mítico-paqarina o fundador, pero ojo, esto no significa solamente. Como hemos visto este ha definido el momento y orden de los hombres a los que anima, como sucede con el caso de Tutayquire que:

"Capitulo 11:

9. un día, Tutayquire dijo [a los checa]: "no estéis tristes, hijos, digan lo que digan; que sigan despreciándolos; en el futuro, vuestro nombre será checa-huillca y los hombres llamaran con menosprecio a estos que os desprecian: "iquinticitos zancuditos!"

10. unos pocos días después Tutayquire poniéndose de acuerdo con sus otros hermanos, empezó la conquista de los yuncas de Llacsatambo."

(Taylor 1987).

También este posee el deseo hostil, el deseo individualizante, aunque no en el sentido que nos propone A. Hernando, no en el sentido estricto del "yo-no yo", el deseo hostil del camac héroe mítico -paqarina o fundador también obedece a un colectivo, si bien es cierto este deseo lo diferencia como momento y orden de los otros camac, se inscribe en un principio andino autárquico de comunidad, así el deseo individualizante obedece también a una diferenciación colectiva, a un "mi comunidad-no mi comunidad". De ahí el sentido de adscripción a una identidad común de culto de los pueblos prehispánicos de Huarochirí en base a estos camac. 
El camac hembra, por su parte representa el poder sobre las emociones, personifica el deseo amoroso que vincula, agrupa, hermana a los hombres en comunidad. Como se había anotado, son los camac machos los que recorren el territorio andino buscando a las camac hembras. Como tal estas permanecen en las tierras de sus comunidades hasta que son descubiertas por estos. Vale recordar aquí un asunto crucial cuando hablamos de los encuentros de los personajes míticos femeninos y masculinos, y es el hecho de que se entabla una negociación de intereses: 1) el camac macho solicita los favores sexuales de su contraparte femenina, 2) el camac hembra solicita canales, puquios, acequias, fuentes de agua, terrazas, etc.

Estas solicitudes tienen un objetivo en específico. Los camac machos buscan poseer el derecho a la heredad de los tiempos de los camac rivales o vecinos, las hembras buscan satisfacer las demandas de su comunidad. Aquí nuevamente el caso de Wichuka es trascendental.

Wichuka al igual que Chuquisuso, solicitan agua a cambio de sus favores sexuales. Recordemos a diferencia de la doncella de Quinti, Wichuka no llega a obtener lo que solicita por lo cual no sede el derecho a su heredad. Como tal, Wichuka no solo personifica exactamente el deseo amoroso, a través de sus solicitudes, sino también personifica el deseo hostil, pues llega a convertirse en camac héroe mítico- paqarina o fundador, se vuelve líder, se impone ante los camac macho.

En el caso andino, estos pasajes del mito, nos sugiere aquella afirmación de A. Hernando, con la que abrimos esta discusión: "No existe el género como algo cerrado, definido, y dado. Creo que lo que existe es sino una diferencia en el porcentaje en que cada persona desarrolla el deseo hostil y deseo amoroso y que llamamos femeninas a aquellas actitudes, creencias, valores, etc. En que el deseo amoroso prevalece y llamamos masculinas a aquellas en que lo hace el hostil" (Hernando 2007:12). Por ende Wichuka puede al igual que los personajes míticos femeninos especializarse en el deseo amoroso, pero también puede haber desarrollado un alto grado de deseo hostil.

Estos niveles de desarrollo parecen incluso llegar a equipararse. Cuando analizamos el caso del engaño a Wichuka, Pachacamac es hembra. Ha de mencionarse un asunto vital, las estrategias en las relaciones sexuales y matrimoniales. Rucanacoto, camac local de la cuenca media alta del Rímac establece relaciones sexuales y matrimoniales con Chaupiñamca. A diferencia de Pachacamac, Pariaqaqa no se transforma en mujer para establecer vínculos con Rucanacoto. En cambio envía a Chaupiñamca. Está claro que esto significa que Pariaqaqa no desea la heredad del momento y orden de Rucanacoto, sino más bien estaría buscando aliarse con este. Lo que se estaría buscando con esto es inducir a los de Rucanacoto hacia una adscripción de identidad al culto a Pariaqaqa. Recordemos que el deseo amoroso, de las camac hembras busca vínculos emocionales y le guía un sentido de colectividad, estos vínculos y relaciones emocionales se reproducen por ende en sociedad. L. Márquez y E. Gonzales nos hablan de la participación de las instituciones de los grupos sociales en la reproducción social de las identidades mediante la socialización (L. Márquez y E. Gonzales 2010: 53-54). El culto en el mundo andino tiene todo el carácter de institución, y a través de la introducción de los niños en la socialización la reproducción social de las identidades puede redirigirse a favor del culto centrado en el poder sobre las emociones, desplazando lentamente en importancia dentro de la comunidad o grupos social al poder hostil del camac macho, Rucanacoto. Por ende a diferencia de Pachacamac que parece haber desarrollado también un alto grado de deseo amoroso, como estrategia para hacerse de alianzas, Pariaqaqa sería un camac especializado en el deseo hostil. Este bien podría estar sugiriéndonos dos formas de vinculación de las estrategias de identidades de género con las identidades de culto en la costa central:

1) Identidades de género en el culto serrano: donde los camac están especializados en un solo tipo de deseo, hostil para los machos, y amoroso para las hembras. 
2) Identidades de género en el culto costeño: donde los camac han desarrollado tanto el deseo amoroso, como el hostil.

Esto no significa que los camac especializados en un tipo de deseo no hayan desarrollado también el otro tipo de deseo, el caso de Wichuka lo demuestra, sin embargo a diferencia del caso de Pachacamac, el grado de desarrollo del deseo amoroso es superior al del hostil, es por eso que no sucede una transformación de hembra a macho.

Además, esto no estaría sugiriendo que los cultos serranos se estén manifestando en un ordenamiento patriarcal. Según Lerner el patriarcado es "la manifestación y la institucionalización del dominio masculino sobre las mujeres y los niños de la familia y la ampliación de ese dominio masculino sobre las mujeres a la sociedad en general. Ello implica que los varones tienen el poder en todas las instituciones importantes de la sociedad y que se priva a las mujeres de acceder a él. No implica que las mujeres no tengan ningún tipo de poder o que se las hay a privado por completo de derechos, influencia y recursos" (T. Escoriza 2002). Debemos acotar que una cosa es un culto patriarcal y otra una organización socio-política patriarcal. Aquí no nos compete tratar asuntos sobre la organización socio-política de los pueblos de Huarochirí, sino la de su culto. No obstante habrá que aclarar en la dimensión del culto, la presencia o ausencia de las formas de violencia patriarcal.

T. Escoriza menciona las formas de violencia patriarcal: exclusión y alejamiento de las mujeres de determinados lugares sociales, la expulsión de las mujeres mediante el lenguaje, la imposición de un orden simbólico sobre ellas, el control material de sus cuerpos y de sus vidas, las mujeres como fetiche erótico, y la explotación o Disimetría entre el trabajo social y el consumo individual (T. Escoriza 2002). Si bien es cierto es difícil hablar en estos términos al hablar de los camac, algunos puntos concordantes con la información presentada en este trabajo parecerá concordar con la imposición del culto patriarcal, como: la mujer como fetiche erótico, la imposición simbólica de los hombres sobre la mujer, o el control de sus cuerpos y sus vidas. Puntos que se pueden adecuar a los datos de las discusiones tratadas.

Al respecto A. Hernando nos dice que una sociedad justa y no-patriarcal no exige que las mujeres se masculinicen, ni que los hombre se feminicen sino que ambos equilibren el deseo amoroso y hostil (Hernando 2007: 13). Si hacemos caso de esta afirmación, la bisexualidad de Pachacamac puede interpretarse como patriarcal. Sin embrago debemos tener en cuenta que la adscripción a una identidad de culto si bien se da a través de los camac héroe mítico-paqarina o fundador se integra a nivel de comunidades por los camac hembras que han cedido el derecho de su potestad al momento y orden de sus comunidades, es decir han otorgado el poder sobre sus comunidades a los camac machos.

El criterio de adscripción a una identidad de culto, necesariamente funciona en base, no al poder político, sino más bien al deseo hostil, el deseo de individualizar a ese culto del de otros camac macho, del de diferenciarse en "mi culto-no mi culto". La dimensión del poder de los camac machos se da en este sentido de carácter público. Pero internamente a nivel de comunidades, tomado el caso de Pariaqaqa: la comunidad de Chuquisuso, la de Miriahuato, la de Chaupiñamca, etc., el deseo amoroso, del poder sobre las emociones es la que define la permanecía y la adscripción a las identidades de culto. Las camac hembras se van con aquellos que logran satisfacer, no necesariamente sus necesidades sexuales, sino las necesidades de fuentes de agua, terrazas y chacras para su comunidad. Si no se logra satisfacer estas necesidades no se gana el control sobre el deseo amoroso, ni se justifica la posesión sobre la potestad del momento y orden de los pueblos, el poder no político, sino emocional sobre ellos. De ahí, que pase como con Tamtañamca que perdió ese derecho al no ser capaz de satisfacer más las necesidades de la comunidad. El hecho que su mujer le sea infiel lo evidencia, y nos indica lo sensible que resulta el poder público o político para mantener el derecho a esta heredad apoderada de las camac hembra 
Finalmente vale resaltar, las afirmaciones de A. Hernando (2007). Nos dice que las mujeres han sido responsables de mantener los vínculos del grupo a lo largo de la historia, a través de la especialización del deseo amoroso. Además, afirma que el deseo amoroso permite que el poder político o el deseo hostil prevalezcan.

Aquello parece ser lo que está aconteciendo en la dinámica de adscripción de identidades de culto de los pueblos prehispánicos de Huarochirí. En este espacio territorial las identidades se adscriben al culto a los camac héroe mítico-paqarina o fundador a través, del deseo amoroso de los camac hembras, al satisfacer periódicamente las necesidades de agua, sobre todo, de las comunidades, solicitadas a través del camac hembra. Recordemos al respecto, que la relación medular de las huacas con lo sagrado se vincula por el don de las huacas de generar fuentes de agua (Gose 1993). Los camac macho se hacen de la posesión del momento y orden, es decir del poder sobre estas comunidades al satisfacer estas necesidades. El deseo hostil les permite individualizar su culto en un espacio determinado. Y esta adscripción de las comunidades al culto de estos camac machos, se sustenta en la posesión en el poder de las emociones y el deseo amoroso de los camac hembras.

\section{LOS ARCHIPIELAGOS DE CULTO ${ }^{22}$}

De la tesis de J. Murra, el control vertical de un máximo de pisos ecológicos, se desprende la visión del terreno andino como múltiples espacios de "territorio salpicado", sin fronteras ni límites definidos, donde el espacio de acción de la gran variedad de grupos "étnicos" o comunitarios se encuentran entrecruzados, fragmentados, discontinuados. Para el modelo de Murra, la gestión de los archipiélagos ecológicos, distantes y discontinuos, ejercen una necesidad en la economía complementaria de los grupos étnicos andinos, que impide a los grupos étnicos definir sus límites y fronteras territoriales. El centro de este modelo es la gestión del grupo comunal para el aprovechamiento de las tierras de diversos pisos ecológicos, este control sobre la producción de diversos ecosistemas permite que los recursos sean gestionados en beneficio del núcleo étnico al cual pertenecen y/o para su curaca al cual rinden obediencia. Así un solo territorio delimitado es contrario a este modelo (Murra 1975).

Esta perspectiva de territorio salpicado, sensible a las fronteras, si bien tiene un fundamento económico, se justifica ideológicamente. El discurso religioso legitima no solo la identidad comunitaria, sino también la labor estratificada y comunitaria de los individuos dentro de la economía étnica.

22. Para el área de Huarochirí, solo se ha podido identificar un caso característico para esta propuesta. No obstante creo que esta forma de inscripción de culto dentro de otro, bien puede darse en toda la costa central. Se ha dicho que Urpayhuachac es hermana de Chaupiñamca y emparentada con Pariaqaqa, su presencia en Pachacamac puede interpretarse tal vez como un archipiélago de culto. Quiero aclarar que con archipiélago de culto no me refiero precisamente al templo de una camac de origen extranjero, no originario, o no primigenio, dentro de un territorio identificado con un camac específico. Aunque en gran parte, se sustenta bajo este principio, el rol de estos camac deben tener trascendencia más allá de la descripción de su templo, a tal magnitud incluso que llegue a rivalizar en determinadas atribuciones o funciones con el camac primigenio u originario, aunque está claro que no rivaliza con la dimensión del alcance del poder de este. Además, es posible que este culto introducido represente los intereses de algún orden político y/o administrativo que vela por sus intereses dentro de una organización comunitaria local. Estos aspectos han de resolverse con una mayor búsqueda de información y análisis, no obstante pienso que este es un caso muy difundido en el territorio andino, sobre todo en tiempos del Tawantinsuyu. 
Bradymir Bravo / La distribucion y organización del territorio de los huarochiri prehispanicos...

El Manuscrito narra el caso de Llocllayhuancupa:

"Capitulo 20:

2. /se dice que/ el huaca que llamamos Llocllayhuancupa era hijo de Pachacamac.

3. al aparecer este huaca, lo encontró una mujer llamada Lantichumpi del ayllu Alaysatpa mientras trabajaba en su chacra.

6. "este será quizás alguna huaca" dijo y decidió llevarlo para mostrarlo a sus padres y a los otros miembros de su ayllu.

7. había en esa época, en la comunidad de Llacsatambo, otro huaca llamado Cataquillay que les había sido regalado por el inga.

8. este Cataquillay poseía la facultad de hacer hablar, sin esfuerzo, a cualquier huaca que no supiera hablar.

9. así hizo también al huaca Llocllayhuancupa preguntándole: “QQuién eres? ¿Cómo te llamas? ¿A qué fin viniste?".

10. entonces, [el otro] respondió: "Yo soy el hijo de Pachacamac, del que hace temblar la tierra y mi nombre es Llocllayhuancupa. Mi padre me ha enviado para custodiar a esta comunidad de los checa."

11. (...) la gente se regocijo mucho diciendo: "ique se encuentre bien en este pueblo mientras nos esté protegiendo!". En la casa de la misma persona que lo había encontrado existía una pequeña cancha; todos lo checa así como los huanri y los chauti, todos, agrandaron esta cancha y prepararon para que fuera digno de ser la casa y la cancha [de Llocllayhuancupa] a quien veneraba mucho."

(Taylor 1987: 293-195).

Según se dice en el Manuscrito, el templo de Llocllayhuancupa estaba situado en Sucyahuillca, en las alturas de San Bartolomé de Suquiacancha. Ahí los ayllu checa de Tutayquire, Allauca y Yasapa cuidaban de los rebaños costeños destinados a Pachacamac (Taylor 1987: 299, Rostoworowski 2002: 213). Por otro lado está la presencia de Cataquillay, camac que "hace hablar a las huacas", usada por los incas para determinar de acuerdo a sus intereses cuales de las huacas tienen la capacidad de la adivinación y la palabra, es decir establece quien es camac o huaca y quien no (Taylor 1987: 293-295):

7. había en esa época, en la comunidad de Llacsatambo, otra huaca llamado Cataquillay que les había sido regalado por el inga.

8. Este Cataquillay poseía la facultad de hacer hablar, sin esfuerzo, a cualquier huaca que no supiera hablar"

Este Cataquillay, bien podría ser el Catequil de Huamachuco, poderoso y famosísimo Apu, con el que se ensañara Atahualpa ante un vaticinio negativo en contra de sus intereses. Recordemos que el prestigio de Catequil radica en su posición como gran oráculo (Topic 2008), además como se ha señalado, la difusión del culto de Catequil al Ecuador se evidencia en la nominación de siete manantiales con el nombre de Catequilla (Topic 2008: 84). Posiblemente denominaciones similares hayan servido para emplear las bondades del oráculo de Catequil en diversas partes del Tawantinsuyu. De ser así, el Cataquillay entre los Huarochirí, sería una de sus tantas representaciones repartidas por todo el Tawantinsuyu como instrumento desestructurador y de control aplicado por el aparato estatal qosqueño en los espacios de cultos regionales. 
Hemos dicho que el espacio del que se apodero Tutayquire comprende las tierras hacia la costa de la margen izquierda del valle medio del Rímac de Mama hasta Pariachi, en el valle medio de Lurin hasta Sisicaya, y habría comprendido las comunidades de San Damián con su adoratorio de Llacsatambo y el pueblo de Conchasica, San Bartolomé de Suquiacancha, Santiago de Tumna ${ }^{23}$, y Tupicocha, (Taylor 1987) las tierras de Cocachacra v Carachacra (Rostoworowski 2002: 211: Bazán 1990: 221).

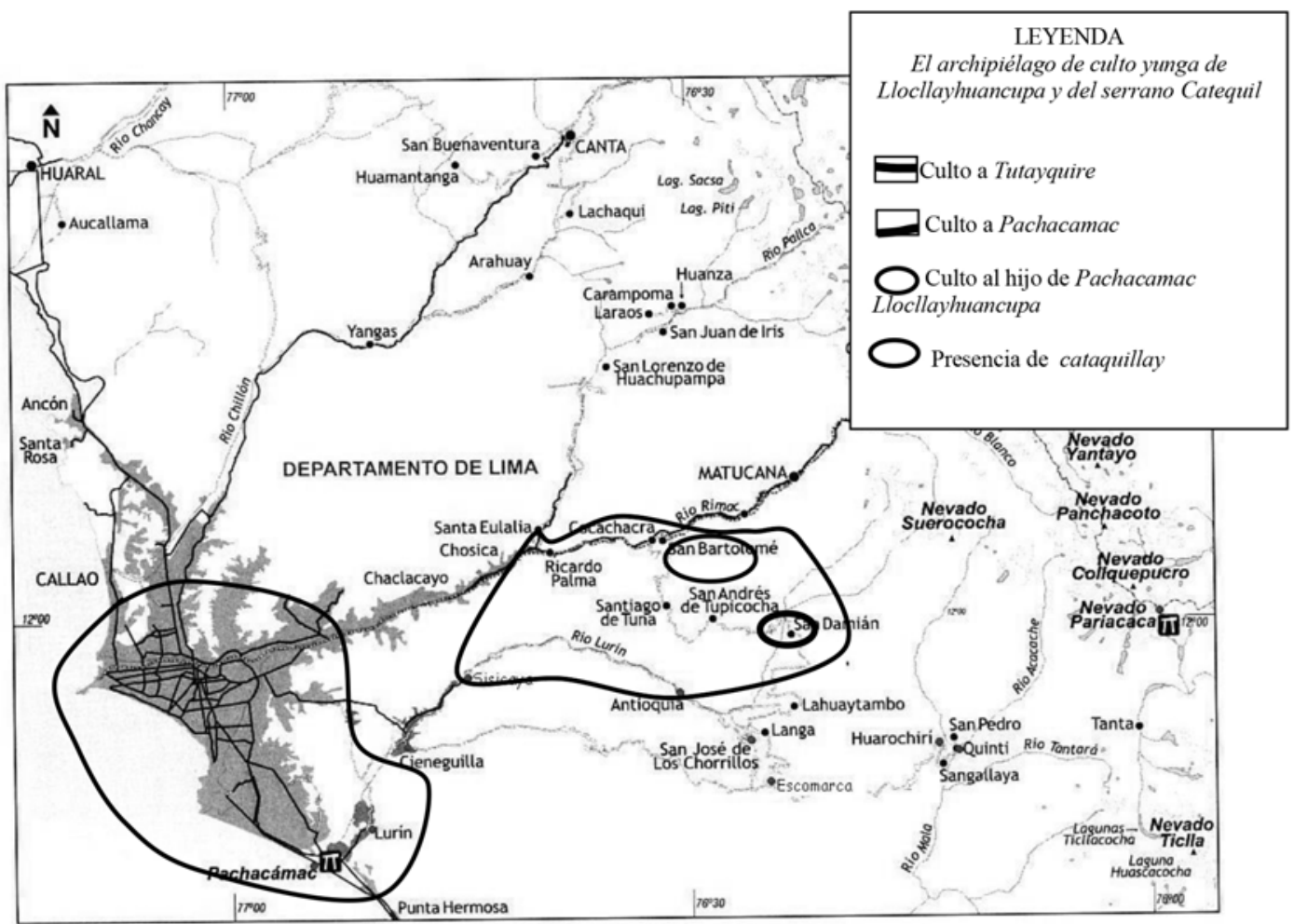

Se ha sostenido además que la adscripción étnica de los pueblos checa, se basa en la identidad al culto a su camac "héroe mítico -paqarina o fundador". Es decir el territorio de los checa es el territorio del culto a Tutayquire.

Por tanto, el hecho de que el culto yunga a Llocllayhuancupa, y el culto extranjero a Cataquillay se inscriba dentro del territorio definido por un culto local bien puede estar indicándonos una dinámica de distribución del territorio del culto del tipo archipiélago en la provincia de Huarochirí, donde el centro de este culto yunga sería el territorio Ychsma y su culto a Pachacamac, y el centro del culto extranjero seria la región de Huamachuco, y su culto a Catequil.

Un caso similar, aunque a mayor escala, estaría sucediendo con el culto a Huallallo Carhuincho en San Pedro de Casta. Como se ha dicho se encuentra flanqueado por el culto a Wampu hacia el noreste (Huanza y Carampoma), por el culto a otro Wampu (quizás Chuquihuampo) hacia el noroeste (Chaclla), muy probablemente flanqueado por el sur con el culto a Tutayquire y Pariaqaqa, y probablemente también hacia el norte al culto relacionado a una hermana de Manañamca, Llunkuwachaq (Lluncuhuachac) que residía por el lado de Canta junto a 4 de sus hermanas (Taylor 1987, Arroyo 2006) -aunque muy probablemente una de sus mujeres también podría ser otra huaca de los locales rivalizados con Huallallo-. 


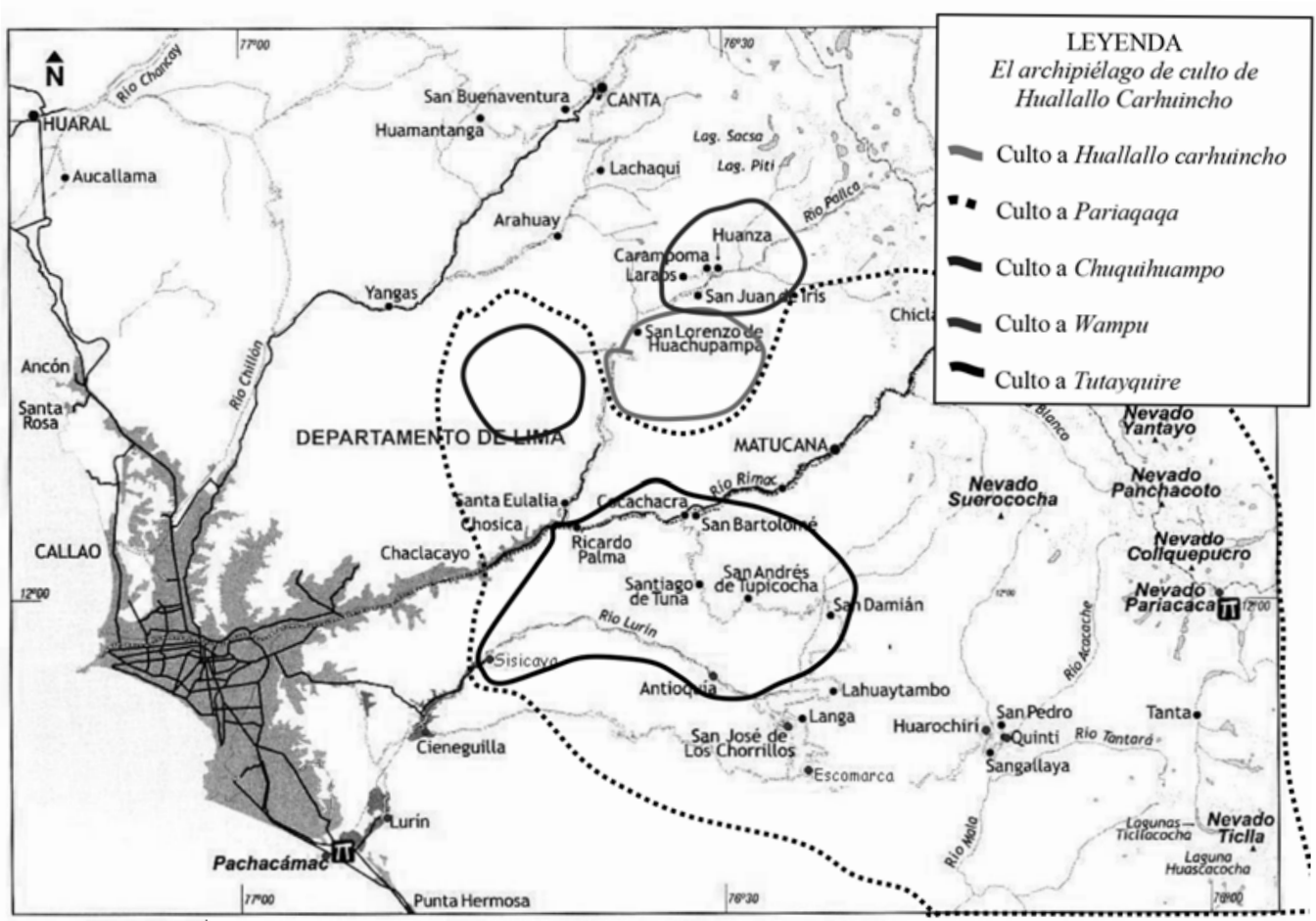

Este cerco de culto no tendría por qué ser un caso de archipiélago, a no ser por una consideración, y es que el territorio originario del culto a Huallallo estaría en los antis, entre los Xauxas y Huancas (Taylor 1987).

En el manuscrito quechua de Huarochirí se narra, que ante el vaticinio que el culto a Pariaqaqa seria abandonado que un Llacuaz, Quita Pariasca, auguro en el corazón de la llama sacrificada al Camac, los yana de Pariaqaqa:

C18: 11. "Llenos de odio y cólera, le dijeron a Quita Pariasca: "¿Qué puede saber un llacuaz, hombre hediondo? Nuestro padre Pariacaca, en todos los confines del Chinchaysuyo tiene hombres a su disposición. ¿Cómo podría ser el abandonado? ¿Qué puede saber ese hombre malvado?”

(Taylor 1987: 279).

Mas allá del acierto de este llacuaz, yana de Pariaqaqa, pues en efecto aconteció que el arribo de los huiracochas cristianos desato la dispersión de los oficiadores del culto a Pariaqaqa, la mención de que Pariaqaqa haya tenido en el extenso territorio del Chinchaysuyo hombres que lo sirvieran resulta para nuestra discusión una revelación.

La mención anteriormente citada parece concordar con una serie de toponimias registradas en la región del Chinchaysuyo por Cesar Astuhuaman (2008). Precisamente en su revisión del caso del oráculo de Pariaqaqa, Astuhuaman ha recuperado un interesante grupo de topónimos asociados al Apu de Huarochirí fuera de la sierra limeña. La presencia de estos topónimos hacia el norte del Perú, 1 en Huaral, 4 en Ancash, 1 en Huánuco, y 1 en Piura, bien podrían estar señalando casos específicos de archipiélagos asociados al culto de Pariaqaqa. 
En el anexo de Huándaro, distrito de Sumbilca en Huaral, se ha reportado la presencia de tierras atribuidas a Pariaqaqa ("Tierras de Pariacaca") (Astuhuaman 2008: 109). Este pasaje nos sugiere la posibilidad de que estas tierras estén destinadas para el beneficio de mitmas de la sierra central de Lima llevados ahí por las políticas del estado inca, cuya identidad se identifica con el culto a Pariaqaqa o también se tratarían de tierras destinadas al cultivo de algún recurso destinado exclusivamente al culto a Pariaqaqa.

Durante las campañas de extirpación de idolatrías de Bernardo de Noboa en la provincia de Bolognesi en 1656 se atestiguó la costumbre de los locales de desenterrar a sus deudos y enterrarlos en base a su tradición en unas cuevas llamadas "Pariacaca Manchay". Así mismo Paz Soldán ha registrado un grupo de aldeas vinculadas toponímicamente a Pariaqaqa en Ancash: registra "Pariacaca" a una aldea de 276 habitantes del distrito de Uco, en la Provincia de Huari, y como "Pariagago" a una aldea del distrito de Pomabamba, mientras German Stiglich registra como "Pariacaca" a una aldea en el mismo distrito; y en el Distrito de Carhuaz (Huaraz) se ha reportado una comunidad llamada "Pariacaca". Un caso similar ha registrado Stiglich en Huánuco, provincia de Dos de Mayo, en el distrito de Jesús, donde "Pariagaga" es el nombre asignado a un grupo de 9 habitantes de un caserío (Astuhuaman 2008: 109-110). Estos casos presentados sugieren la presencia de mitmas adscritos al culto al Apu Pariaqaqa en tierras extranjeras, donde impera el culto a un camac diferente. La lejanía de sus espacios de origen habría intensificado la identidad de culto de estos mitma, lo cual se ve reflejado en sus intentos por construir un espacio simbólico de re-memorización de su identidad de culto y resistencia ante el culto extranjero.

Finalmente un caso especial se ha registrado en Huancabamba, Piura, donde se ha reportado un cerro denominado Pariacaca, en cuyas aproximarías se extendería un pequeño cementerio de tumbas prehispánicas (Astuhuaman 2008: 110-111). Este ejemplo refleja hasta qué grado la re-memorización del culto a Pariaqaqa y la resistencia a un culto de tierras extranjeras se evidencia en estos mitmas.

De lo mencionado anteriormente se concuerda la contemporalidad de los casos en tiempos del Tawantinsuyu. Si concebimos dentro de este espacio temporal la posibilidad de organizar y distribuir el territorio en base al culto de una categoría de camac que represente la adscripción a una identidad comunitaria propia de los pueblos (como es el caso del camac "héroe mítico-paqarina o fundador" para la sierra de Huarochirí) es muy posible toparnos con un organización muy compleja del territorio: con limites más flexibles que rigurosos, con espacios de culto salpicados dentro de otros espacios mayores de culto, con varios y pequeños espacios de culto a camac extranjeros insertados en el espacio de un culto local. Si concebimos esta posibilidad es probable que el panorama del territorio andino en tiempos del Tawantinsuyu se exprese en un complejo y variado sistema de archipiélagos, es probable que este sistema de organización haya sido una expresión del control y administración activo del aparato estatal inka. Aún queda por precisar ¿Cómo es que funcionaba esta dinámica de archipiélagos de culto? ¿A qué escala o magnitud se sustentaba su dependencia del centro cultista? ¿Cómo afectaba este al momento y orden del culto local? ¿Cuáles son las implicancias políticas y económicas que estarían justificando este tipo de dinámica? ¿Cuál es el papel del estado inka en el funcionamiento de este tipo de dinámica de culto? ¿Se trata de un principio andino muy antiguo, anterior a los inka? Sin duda un más profundo análisis de un mayor número de casos en tiempos del Tawantinsuyu pueda aclarar este panorama.

\section{BiBLIOGRAFÍA}

AMAT OLAZABAL, Hernán.

1992 “Los Yaros en la Historia de Huarochirí". Huarochirí ocho mil años de Historia, Tomo I. Municipalidad de Santa Eulalia de Acopaya. Lima. pp. 67-116. 
ARGUEDAS, José María

1966 Dioses y hombres de Huarochirì. Instituto de Estudios Peruanos. Lima

ARRIAGA, Fray Pablo J.

1621 (1999) Extirpaciones de la idolatría del Perú. Centros de Estudios Regionales Andinos "Bartolomé de Las Casas". Cuzco-Perú. pp. 200.

ARROLLO AGUILAR, Sabino.

2006 Culto a los hermanos Cristo. Sistema religioso andino y cristiano: redes y formas culturales del poder en los Andes. Tesis para optar grado de doctor en ciencias sociales: especialidad antropología, Universidad Nacional Mayor de San Marcos. Lima-Perú.

ASTUHUAMÁN GONZÁLES, Cesar.

2008. Los otros Pariacaca; oráculos, montañas y parentelas sagradas. Adivinación y oráculos en el mundo andino antiguo. Instituto Francés de Estudios Andinos - Pontificia Universidad Católica del Perú, Lima. pp. 97-119.

2011. The concept of Inca province at Tawantinsuyu. INDIANA 28. pp. 79-107.

BARTH, Fredrick.

1969. Ethnic Groups and Boundaries. The Social Organization of Culture Difference. Oslo and London: Universities Forlaget.

BAZAN DEL CAMPO, Francisco J.

1990 Arqueología y etnohistoria de los periodos tardíos de la Costa Central del Perú. Tesis de licenciatura en arqueología (UNMSM). Lima-Perú.

CARCELEN RELUZ, Carlos G.

1994 “Doctrinas y doctrineros. Sierra Limeña siglo XVI-XVII”. Nueva síntesis. Año 1. n 1-2. Lima.

1996 Las doctrinas de Chaclla-Huarochirí, siglos XVI-XVII. Organizaciones y desarrollo de las parroquias rurales en el Perú Colonial. Tesis (UNMSM). Lima- Perú.

DAVILA BRICEÑO, Diego.

1881-1897/1965 Descripción y relación de la provincia de los Yauyos toda, Anan Yauyos y Lorin Yauyos, hecha por diego Dávila Brizeno, corregidor de Guarocheri. En Jiménez de la Espada: Relaciones geográficas de Indias. Madrid: Ediciones Atlas. Biblioteca de Autores Españoles, tomo 183. pp. 310-409.

\section{ESCORIZA MATEU, Trinidad}

2002 "Mujeres, arqueología y violencia patriarcal". En actas del congreso interdisciplinar sobre violencia de género. m.t. López Beltrán et al. (eds.), violencia y género. Tomo I. Málaga. Pg. 59-74

FELTHAM, Jane.

2005 "Yungas and Yauyos. The interface between archeology and ethnohistory as seen from the Lurin valley". En: Wars and conflicts in prehispanic Mesoamerica and the Andes. B.A.R. International series 1385. Pg. 128-145.

GENTILLE LAFALLE, Margarita.

1976 a Los Yauyos de Chaclla: del siglo XV a XVIII. Tesis de bachillerato, UNMSM. Lima-Perú.

1976 b Distintos aspectos de tributos entre los Yauyos de Chaclla (s XV-XVIII). Boletín del IFEA V, N³-4. Lima-Perú.

1977 “los Yauyos de Chaclla: pueblos y ayllus (s XVIII)”. Boletín del IFEA VI, n³-4. Lima-Perú.

GOSE, Peter.

1993 "Segmentary state formation and the Ritual Control of Water Under the Incas". Comparative Studies in Society and History. vol. 35, N 3.pp 480-514. 
HERNANDO GONZALO, Almudena.

2007 "sexo, género y poder. Breve reflexión sobre algunos conceptos manejados en la arqueología de género". Departamento de Prehistoria, Universidad Complutense. Vol. 18. Madrid-España. pp. 7-14.

LIZARRAGA IBAÑEZ, Manuel.

2009 "Lo ceremonial en el contexto de la vida secular. Asentamiento urbano del período Horizonte tardío: Pueblo Viejo - Pucará, valle de Lurín". Arqueología y sociedad, N²0. pp. 131-148.

MARQUEZ MORFIN, Lourdes y Ernesto GONZALES LICON

2010 "La socialización de los niños en el pasado. Algunas reflexiones y propuestas en torno al tema". En Los niños, actores ignorados. Levantando el velo, una mirada al pasado. Instituto Nacional de Arqueología e Historia. México. pp. 51-74.

MURRA, J. V.

1972. El Control Vertical de un Máximo de Pisos Ecológicos en la Economía de las Sociedades Andinas. In: J. MURRA, ed. Visita de la provincia de León de Huánuco en 1562. Huánuco: Universidad Nacional Hermilio Valdizán, 29-476.

ORTIZ RESCANIERE, Alejandro.

1993 La pareja y el mito. Estudios sobre las concepciones de la persona y de la pareja en los andes. Fondo editorial Pontificia Universidad Católica del Perú. Lima-Perú. pp. 261.

RAMON JOFFRE, Gabriel.

1999 "Producción alfarera en Santo Domingo de los Olleros (Huarochirí-Lima)". Bull. Inst. fr. Estudies Andines. Vol. 28, n². pp. 215-248.

ROSTOWOROWSKI DE DIEZ CANSECO, M.,

1977 Etnia y Sociedad: Costa Peruana Prehispánica. Lima: Instituto de Estudios Peruanos.

1978 Señoríos Indígenas de Lima y Canta. 280p.; Lima: Instituto de Estudios Peruanos.

1992 Pachacamacy el señor de los milagros. Una trayectoria milenaria. Instituto de Estudios Peruanos. pp. 215.

2002 “Señoríos indígenas de lima y canta”. En Obras completas de María Rostoworowski, volumen II. Instituto de Estudios Peruanos. Lima-Perú.

\section{SALOMON, Frank}

1997 “Los quipus y libros de la Tupicocha de hoy: un informe preliminar" Arqueología, antropología e historia en los Andes: homenaje a María Rostworowski. Instituto de Estudios Peruanos. Lima, pp. 241-258.

SHADY SOLIS, Ruth.

1998 "Entre el mito y la realidad: la importancia de la coya en la sucesión del estado inca, de Hurin y de viracocha”. En Arqueología y Sociedad, N²12. pp. 51-61.

TAYLOR, Gerald.

1987 Ritos y tradiciones de Huarochirí. Instituto de Estudios Peruanos. pp. 617.

TELLO, J. C y Miranda, Prospero.

1923 “Wallallo. Ceremonias gentiles realizadas en la Región Cisandina del Perú Central. (Distrito arqueológico de Casta)”. Revista Inca. UNMSM. Vol. 1 N². Abril-Junio. Lima-Perú.

TOPIC, John R.

2008 "El santuario de Catequil: estructura y agencia. Hacia una comprensión de los oráculos andinos." In: M. CURATOLA y M. ZIOLKOWSKI, eds. Adivinación y oráculos en el mundo andino antiguo. Lima: Instituto Francés de Estudios Andinos - Pontificia Universidad Católica del Perú. pp. 71-95. 